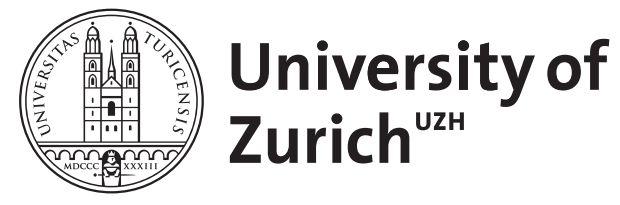

\title{
Alternative roles for metal ions in enzyme catalysis and the implications for ribozyme chemistry
}

\author{
Sigel, Roland K O ; Pyle, A M
}

DOI: https://doi.org/10.1021/cr0502605

Posted at the Zurich Open Repository and Archive, University of Zurich ZORA URL: https://doi.org/10.5167/uzh-79689

Journal Article

Accepted Version

Originally published at:

Sigel, Roland K O; Pyle, A M (2007). Alternative roles for metal ions in enzyme catalysis and the implications for ribozyme chemistry. Chemical Reviews, 107(1):97-113.

DOI: https://doi.org/10.1021/cr0502605 


\title{
Alternative Roles for Metal Ions in Enzyme Catalysis and the Implications for Ribozyme Chemistry
}

\author{
Roland K. O. Sigel, ${ }^{* \dagger}$ Anna Marie Pyle ${ }^{*}, \star$ \\ Institute of Inorganic Chemistry, University of Zürich, Winterthurerstrasse 190, CH-8057 Zürich, \\ Switzerland, and Department of Molecular Biophysics and Biochemistry, Howard Hughes Medical \\ Institute, Yale University, 266 Whitney Avenue, New Haven, CT 06520, USA
}

*To whom correspondence should be addressed: R.K.O.S.; email, roland.sigel@aci.unizh.ch; phone, ++41-44-635 4652; fax, ++41-44-635 6802. AMP.; email, anna.pyle@yale.edu; phone, ++1-203-432 5633; fax, $++1-203-4325316$.

${ }^{\dagger}$ Institute of Inorganic Chemistry, University of Zürich

${ }^{\ddagger}$ Department of Molecular Biophysics and Biochemistry, Howard Hughes Medical Institute, Yale University 
February 23, 2006; Sigel \& Pyle

\section{Contents}

1. Introduction

2. The Increased Complexity of Group Transfer Catalysis by Metalloenzymes

3. Metal Ion-Binding Sites in Proteins and Ribozymes

3.1. Metal Ion-Binding Sites in Proteins

3.2. Metal Ion-Binding Sites in RNA

4. Promoting Catalysis with Charge: Electrostatic Effects

4.1. Localized Charges Can Modulate the Reactivity of Enzyme Functional Groups

4.2. Electrostatic Induction by Divalent Metal Ions

4.3. Switching Charge Types in Proteins: Metals for Lysine and Vice Versa

4.4. Electrostatic Induction of $\mathrm{p} K_{\mathrm{a}}$ Shifts in Nucleic Acids: Lessons from Nucleobase Model Systems

4.4.1. Modification of Purine Acidity

4.4.2. Modification of Pyrimidine Acidity

4.4.3. Effect of Backbone Functionalities

4.4.4. Water-Hydroxide Equilibria and the "Metal Ion Switch Experiment"

4.4.5. Further Reasons for $\mathrm{p} K_{\mathrm{a}}$ Shifts

4.5. The Distance-Dependence and Additivity of Charge Effects

5. Metal Ion Catalysis through Outersphere Interactions

6. Catalysis by Monovalent Metal Ions

7. A Reduced Solvent Polarity Promotes Reactivity

8. Conclusions

9. Acknowledgments

10. References 


\section{Introduction}

Ribozymes can catalyze a large variety of different reactions, but only few mechanistic aspects are understood in detail. ${ }^{1-9}$ It is evident that RNAs are always associated with metal ions, ${ }^{10-14}$ but there have been several studies indicating that ribozymes such as the hairpin, ${ }^{15-19}$ hammerhead, ${ }^{18}$ and certain in vitro selected ribozymes ${ }^{20}$ or DNAzymes $^{21}$ can promote catalysis also in the absence of $\mathrm{Mg}^{2+}$ or related divalent ions. In some of these cases, coordinatively saturated complexes such as cobalt(III) hexammine, or cationic organic molecules such as spermine, and also high concentrations of monovalent ions have been found to substitute for $\mathrm{Mg}^{2+}$ or other divalent metal ions and stimulate catalysis. This finding has led to the suggestion that divalent metal ions, which remain the most catalytically efficient cofactor in most of these cases, are not specifically involved in the chemical mechanism of catalysis by these ribozymes. It is common to conclude in these cases that cations are required only for neutralizing the negative charge of the phosphodiester backbone or to promote structural stabilization.

Most studies on the mechanistic role of metal ions in ribozyme active-sites are designed only to detect catalytic metal ions that interact directly with polarized atoms at the reaction site. They tend to emphasize application of the "metal ion specificity switch experiment", ${ }^{22,23}$ whereby important functionalities such as the the 3'-oxygen leaving group of an RNA phosphodiester linkage are replaced by sulfur substituents. In cases where the altered ribozyme is unable to react in the presence of $\mathrm{Mg}^{2+}$ alone, but activity is restored by the addition of $\mathrm{Mn}^{2+}$ or the thiophilic $\mathrm{Cd}^{2+}$ or $\mathrm{Zn}^{2+}$ ions, ${ }^{14,22-}$ ${ }^{28}$ it is possible to implicate direct inner-sphere contacts between the divalent cation and specific active-site functional groups. ${ }^{22-28}$ While this approach is a powerful tool for dissecting the mechanism of ribozyme catalysis or RNA folding, it may place an undue emphasis on the need to observe direct innersphere contacts between metal ions and ribozymes (or their substrates) in order to account for transition-state stabilization. For example, the existence of a metal ion specificity switch is good evidence for a direct contact between specific functional groups and a metal ion; ${ }^{12}$ but the 
lack of a switch is often taken as tacit evidence that divalent ions do not play a role in catalysis. This is because it is often assumed that a metal ion must touch, or form direct contacts, with highly charged phosphoryl oxygens, the nucleophile, or the leaving group in order to play a critical role in stimulating a reaction.

However, numerous results from the field of protein enzymology have demonstrated that divalent (and often monovalent) metal ions can play an essential role in chemistry without forming direct contacts to any of the substituents in the active site of the enzyme or to the substrate. ${ }^{29}$ These studies have revealed a variety of catalytic strategies for lowering the energetic barrier to reaction. For example, the concentrated positive charge of divalent metal ions can stabilize the anionic transition states of phosphoryl and acyl transfer reactions. Moreover, these electrostatic contributions to reaction are not always short-range effects: they can occur over strikingly long distances. Particularly interesting are mechanisms in which metal ions (or other localized charges like ammonium groups) create an electrostatic environment that alters the $\mathrm{p} K_{\mathrm{a}}$ or nucleophilicity of adjacent functional groups, which themselves can now participate directly in chemical reaction. Other mechanisms involve "outersphere" interactions between substrate functionalities and water molecules that surround a metal ion. In the latter case, a combination of electrostatic and hydrogen bonding effects stimulates the reaction.

Given the diversity of ways that metal ions and positive charges facilitate chemical reactions in model systems and in protein metalloenzymes, it is important to consider that in a ribozyme a metal ion may not behave the way one commonly expects (i.e., binding directly to a polarized group in the transition-state), and that it need not be located precisely at the active site. However such an "illmannered" metal ion may still play a critical and direct role in catalysis by a ribozyme. To exemplify these concepts, we will consider some of the ways that model systems and protein enzymes utilize metal ions for catalysis. We will then relate these observations to recent work in ribozyme enzymology. 


\section{The Increased Complexity of Group Transfer Catalysis by Metalloenzymes}

In metalloproteins, catalytic metal ions often serve as redox-active centers and as cofactors in the so-called polar or "group-transfer reactions". The latter include acyl and phosphoryl transfer reactions, which are also the most common form of reactions catalyzed by ribozymes. Given their importance in ribozyme chemistry, this review will focus on metal ion catalysis of group transfer reactions and their stimulation by metal ions. A comparison of metal ion-catalyzed group transfer reactions in model systems and in protein enzymes provides an important clue to the inherent complexity of metal ion catalysis in enzymes as well as ribozymes.

Metal ion catalysis of group transfer reactions has been described very simply: Reaction should be stimulated if complex formation with a metal ion is more pronounced in the transition state than in the ground state. ${ }^{30}$ Based on the Arrhenius equation, this is described by a simple relation (1), ${ }^{30,31}$

$$
k_{\mathrm{c}} / k_{\mathrm{o}}=K_{\mathrm{T}} / K_{\mathrm{R}}
$$

which defines the rate-enhancement factor, $k_{c} / k_{0}$. The constants $k_{\mathrm{c}}$ and $k_{\mathrm{o}}$ represent the rates of the catalyzed and uncatalyzed reactions, respectively, and $K_{\mathrm{T}}$ and $K_{\mathrm{R}}$ are the stability constants of the metal ion complexes in the transition state and of the reactant, respectively. If one can measure the the rate-enhancement factor, $k_{\mathrm{c}} / k_{\mathrm{o}}$, and the stability constant in the ground-state $\left(K_{R}\right)$, then one can deduce the stability constant of the complex in the transition state $\left(K_{T}\right)$ and speculate about its structure and the role of a catalytic metal ion in the transition state.

Equation (1) describes the narrowest possible role for metal ions in group transfer catalysis: i.e. direct metal ion coordination to atoms in the transition-state. As such, it describes catalysis in certain model systems very well, as exemplified by the metal ion-promoted decarboxylation of acetone dicarboxylate studied by Prue ${ }^{32}$ more than 50 years ago. He discovered that the rate-enhancement factor for different metal ions is proportional to the stability of the malonate complexes of these metal ions. This indicates that the transition state of the decarboxylation reaction resembles the 
structure of a metal-malonate complex. Indeed, a plot of $\log k_{\text {rate }}$ for the metal ion-promoted decarboxylation versus $\log K_{\text {stability }}$ of the metal ion-malonate complexes results in a straight line. ${ }^{33}$ The catalytic effectiveness of divalent metal ions in this decarboxylation reaction increases in the series, $\mathrm{Mg}^{2+}<\mathrm{Mn}^{2+}<\mathrm{Zn}^{2+} \leq \mathrm{Co}^{2+}<\mathrm{Ni}^{2+}<\mathrm{Cu}^{2+}$, which corresponds perfectly to the Irving-Williams series that classifies the order of complex stabilities: ${ }^{34,35} \mathrm{Ba}^{2+}<\mathrm{Sr}^{2+}<\mathrm{Ca}^{2+}<\mathrm{Mg}^{2+}<\mathrm{Mn}^{2+}<\mathrm{Fe}^{2+}<$ $\mathrm{Co}^{2+}<\mathrm{Ni}^{2+}<\mathrm{Cu}^{2+}>\mathrm{Zn}^{2+}$. Several additional simple systems like the metal ion catalyzed hydrolysis of amino acid esters and amides have been studied with analogous results. ${ }^{30,33}$ It should also be mentioned in the present context of this review that the metal ion promoted dephosphorylation of ATP to ADP also follows to a large extent the above mentioned trend of the Irving-Williams series. $^{30,36,37}$

One might expect that for a simple enzyme, where the primary catalytic function of the metal ion cofactor is direct coordination of atoms in the transition state, that a corresponding series for stimulation by different metal ions will be observed. However, for most metal ion-dependent enzyme systems, the situation differs significantly. ${ }^{29,30,33}$ This deviation can be ascribed to many obvious features of the protein environment, including size restrictions on metal ion radii or distinct coordination preferences that result from limitations in nature of available ligands (vida infra). The protein environment can also alter expected metal ion hydroxo-complex formation. But the striking deviation from the Irving-Williams series may also point to an increase in the mechanistic complexity of metal ion catalysis by macromolecules. It suggests that metal ions are generally doing more than forming strong, direct interactions in the transition-state. The pronounced influence of metal ions on electrostatic potential, dielectric constant and other physical characteristics of the macromolecule will have a profound influence on its capabilities as an enzyme.

The situation is expected to be even more complicated with ribozymes, as metal ions tend to bind to ribozymes more weakly than they bind to proteins. For example, $\log K_{\mathrm{a}}$ values for $\mathrm{Ca}^{2+}$ binding to RNA typically range from 1.5 to $2.5,{ }^{38}$ whereas $\log K_{\mathrm{a}}$ values of $\sim 10$ can be reached for 
$\mathrm{Ca}^{2+}$ binding to subtilisin. ${ }^{29}$ Even more extreme differences in the metal ion affinities of proteins and RNA are observed with metal ions like $\mathrm{Cd}^{2+}$, where the sulfur ligands of proteins lead to $\log K_{\mathrm{a}}$ values of $17 .{ }^{39}$ By contrast, $\log K_{\mathrm{a}}$ values for $\mathrm{Cd}^{2+}$ binding to nucleotides and to RNA typically range from 2 to $4 .^{40-42}$ As a consequence of weaker metal ion affinity for nucleic acids, $K_{\mathrm{R}}$ and $K_{\mathrm{T}}$ in equation (1) are likely to be more similar for ribozymes and thus one does not expect very large rateenhancement factors based on relation (1) alone. A more complex role for metal ions in ribozyme catalysis is consistent with the observed metal ion dependencies of ribozyme rate-enhancements, ${ }^{43-48}$ which are inconsistent with equation (1) and therefore with a purely coordinative role for metal ions at the active site in catalysis.

\section{Metal lon-Binding Sites in Proteins and Ribozymes}

Although proteins and RNA molecules both utilize metal ions to catalyze certain transformations, there are salient differences in the way that the ions are bound. This can have important repercussions for the mechanistic function of the metal ions in catalysis.

It is useful to precede any structural description of metal ion binding with a brief overview of the diverse catalytic roles played by metals in both protein enzymes and ribozymes. Metal ions participate in enzyme catalysis through direct and indirect mechanisms and they can also stabilize the active structural form of the enzyme. The highly specific and direct roles of metal ions in group transfer reactions have been particularly well-studied. For example, in certain phosphoryl transfer reactions, divalent metal ions are generally believed to form direct interactions with the polarized phosphoryl oxygen and/or oxygens of the leaving group and nucleophile. By working singly or in groups, these metals provide scaffolding for the transition-state geometry, helping to reinforce the trigonal bipyramidal form of the transition-state. ${ }^{49-54}$ Similarly, they can help align the nucleophile with the reactants, thereby reducing entropic barriers to reaction. Just as important, however, are the many enzymes that employ metal ions for essential catalytic functions that do not involve direct 
physical contacts with polarized atoms of the transition-state. These include enzymes such as ribonuclease $\mathrm{H}$, farnesyl transferase, bovine liver rhodanese and the kinase $\mathrm{p} 21$ ras, in which metal ions alter the $\mathrm{p} K_{\mathrm{a}}$ values of reactive groups and help modulate the electrostatic environment of the active-site (see Section 4.2.).

\subsection{Metal Ion Binding Sites in Proteins}

Metal ions tend to bind protein sites with high affinity and site-specificity. Because the peptide backbone is uncharged, an abundance of weak, nonspecific metal ion binding is not typically observed in protein enzymes. Proteins tend to interact with metals through a limited set of liganding groups, which include the sulfide residue of cysteine, the imidazole moiety of histidine and the carboxylate side chains of aspartic and glutamic acids. The affinity for imidazole and carboxylate ligands stems from two major effects: (1) At physiological $\mathrm{pH}$ (ca. 7.5) the competition between protons and multivalent metal ions for binding at the mentioned $\mathrm{O}$ and $\mathrm{N}$ sites is very small or nonexistent, making these sites readily accessible for metal ions. ${ }^{55}$ (2) There is a synergistic effect for transition metal ion binding simultaneously to heteroaromatic $\mathrm{N}$ sites $(\mathrm{N}$-arm), including imidazole, and O-donor ligands. ${ }^{56-59}$ This is attributed to the fact that the $\pi$-accepting properties of pyridine-type ligands increases the charge of the metal ion and thus favors binding at the negatively charged oxygen ligands ( $\sigma$-donors), ${ }^{59-61}$ an effect that is also reflected in catalysis. ${ }^{60,62}$ Although their participation is less common, there are other functional groups that participate in metal ion binding: The thioether group of methionine, the phenolate residue of tyrosine ${ }^{29}$ the hydroxyl groups of serine and threonine and the carbonyl units of asparagine and glutamine are occasionally observed to form weak binding sites for metal ions. ${ }^{29}$ The carbonyl groups of the peptide backbone can also serve as a site of metal ion coordination, particularly for calcium proteins..$^{29,63}$ To conclude, despite the large number of 


\section{Figure 1 close to here}

amino acids, there are only three highly typical sites for metal ions in proteins, namely the carboxylate, imidazole, and sulfide groups of aspartic/glutamic acid, histidine, and cysteine, respectively (Figure 1). The different combinations of these four amino acids (together with the three-dimensional fold of the protein) lead to binding pockets that are highly selective and which bind the metal ion very strongly.

\subsection{Metal lon Binding Sites in RNA}

The latter behavior contrasts sharply with the metal ion binding properties of RNA molecules, where the diversity of monomer units is low (limited to four nucleobase types) and where the number of potential metal ion-binding sites is large (Figure 1$):{ }^{64}$ Potential sites of interaction include the atoms of each phosphodiester linkage, ${ }^{65}$ the N7 and N3 atoms of purine nucleobases, ${ }^{66,67}$ the N1 of adenine, the $\mathrm{N} 3$ of cytosine, ${ }^{68}$ as well as the carbonyl oxygens at $\mathrm{C} 6$ in guanosine,${ }^{42,69}$ and at $\mathrm{C} 2$ and C4 in the pyrimidines. ${ }^{68,70}$ These sites are unprotonated and therefore accessible for metal ion binding at physiological $\mathrm{pH}$. However, all of the nitrogen ligands described above are generally less basic than imidazole and therefore their metal ion binding affinity (e.g., towards $\mathrm{Zn}^{2+}$ ) is comparatively reduced. ${ }^{71}$ Important exceptions include nucleobases for which heteroatom $\mathrm{p} K_{\mathrm{a}}$ values have shifted (Section 4.4.) and stronger forms of $\mathrm{Mg}^{2+}$ binding that are additionally mediated through outersphere coordination (Section 5.). ${ }^{68-70}$ The very basic sites, (N1)- of guanine $e^{42,67,72}$ and $(\mathrm{N} 3)^{-}$of uracil ${ }^{70}$, as well as the exocyclic amino groups ${ }^{73,74}$ are usually unavailable for metal ion binding. ${ }^{75}$ A final consideration is that the $\mathrm{N} 1$ and $\mathrm{N} 7$ sites of adenine, ${ }^{76,77}$ the $(\mathrm{N} 1)^{-}$and $\mathrm{N} 3$ sites of guanine and the N3 site of cytosine ${ }^{68}$ are somewhat handicapped in their metal ion-binding properties due to steric inhibition by neighboring amino groups. Taken together, this multitude of low-affinity coordination sites often results in metal ion binding that is nonspecific and dynamic in RNA.

Based on a diversity of biochemical and structural investigations, one can differentiate at least 
four ways that metal ions bind to RNA: $:^{78,79}$ (1) Nonspecific charge-screening ions. Before nucleic acid macromolecules can collapse into a discreet structural form, the charge on the polyanionic backbone must be neutralized. This is accomplished by a "cloud" of monovalent or divalent ions that associate weakly with the backbone. Charge-screening was first described by Manning and Record for DNA stabilization and the electrostatic influence of these ions can be described mathematically by continuum electrostatics approximations such as the Poisson-Boltzman distribution. ${ }^{78-89}$

Electrostatically localized metal ions. Certain RNA structures contain specific, well-defined sites that bind metal ions with somewhat higher affinity. These are often pockets, or "holes" in the structure that are characterized by a concentration of negative electrostatic potential. In certain cases, site-binding can be mediated exclusively by electrostatic affinity between the ion and the site. ${ }^{79}$ Because these sites do not interact with metals through specific hydrogen bonding or direct coordination, it is likely that they will be filled by diverse metal ion types, including coordinatively saturated ions such as cobalt hexammine, and by protonated organic polyamines, depending on the site geometry. (3) Inner-sphere site-bound metal ions. In these instances, metal ions interact directly with RNA functional groups (inner-sphere coordination). Remarkably, one of the most coordinatively saturated forms of RNA site-binding is observed for potassium, which commonly fills almost every coordination site through direct interactions with RNA ligands such as phosphoryl oxygens and base heteroatoms. ${ }^{90}$ For obvious reasons, these sites tend to be highly specific for a given metal ion. (4) Outer-sphere site-bound metal ions. In these cases, the interaction of the metal ion with RNA occurs through water molecules (outer-sphere coordination). In many cases (particularly with $\mathrm{Mg}^{2+}$ ), this type of binding is characterized by an extensive network of hydrogen bonding interactions between the RNA and water molecules of the first and also the second hydration sphere of the metal ion. ${ }^{91,92}$ Outer-sphere binding does not necessarily mean that binding is unspecific and weak. To the contrary, every water molecule can contribute to binding by forming two hydrogen bonds to specific acceptor sites on the RNA. Every hydrogen bond can add up to 20-25 
February 23, 2006; Sigel \& Pyle

$\mathrm{kJmol}^{-1}$ in stability, and thus quite high thermodynamic stabilities can such be reached. As in case (3), also when coordinated via outer-sphere interactions, binding of the metal ion to the RNA is likely to be additionally stabilized by a strong electrostatic component.

It is evident that only in rare cases can a metal ion be categorized strictly into just one of these four classes. A detailed evaluation of the crystal structure of the large ribosomal subunit from Haloarcula marismortui revealed $116 \mathrm{Mg}^{2+}$ and 88 monovalent ions bound to the rRNA. ${ }^{92}$ Out of the identified $\mathrm{Mg}^{2+}$ ions, only nine are fully outer-sphere bound, whereas all others show at least one inner-sphere coordination. Such inner-sphere coordination mainly takes place at a non-bridging phosphate oxygen, but also at the N7 site or a carbonyl oxygen. It is thus evident that based on the binding pocket and the geometrical distribution and distances of the coordination sites and hydrogen bond acceptors on the RNA, $\mathrm{Mg}^{2+}$ either binds in an inner-sphere manner or uses a water molecule to bind outer-sphere. It is also feasible that a single $\mathrm{Mg}^{2+}$ ion will change its ligation state over time, i.e. that it will switch between inner-sphere and outer-sphere coordination if both possibilities are energetically similar.

The above mentioned points implicate that classes (2), (3), and (4) encompass a large number of metal ions in every RNA, and that they will have similar affinities. Indeed, measured affinity constants $K_{\mathrm{a}}$ are mainly in the order of $5 \cdot 10^{2}$ to $5 \cdot 10^{3} \mathrm{M}^{-1}$ (in the presence of $0.1 \mathrm{M} \mathrm{Na}^{+}$or $\left.\mathrm{K}^{+}\right) \cdot{ }^{13,78,93-95}$ Nevertheless, at certain sites higher affinities of $\sim 2.5 \cdot 10^{4} \mathrm{M}^{-1}$ have been measured $\left(\left[\mathrm{M}^{+}\right] \approx 0.1 \mathrm{M}\right) \cdot{ }^{78,96}$ In summary, this "cloud" of metal ions around RNA allows the ions to be involved in structural and catalytic processes in more subtle ways than is possible for proteins, where a rigid coordination sphere of few metal ions limits the eminent function.

The generally lower affinity of metal ions for RNA relative to proteins has been attributed to a reduced flexibility of the protein backbone, which contains only two freely rotable bonds compared to six such bonds in nucleic acids. ${ }^{12}$ In addition, the large number of hydrophobic amino acid side chains is thought to cause particularly dense packing in proteins that results in highly preorganized 
active sites and other cavities into which specific metal ions just "fit". This rigidity may produce "constrained" metal ion-binding sites that are particularly conducive to catalysis. ${ }^{97,98}$ Enhanced backbone flexibility and weaker overall metal binding does not, however, mean that ribozymes are $a$ priori disfavored in catalytic processes. Rather, it implies that ribozymes employ other strategies to build up three-dimensional structures, form specific metal ion binding sites and be successful catalysts. A major strategy involves stacking interactions, for which the nucleobases, especially the purines, ${ }^{99,100}$ are perfectly suited. In addition, unusual forms of hydrogen bonding leads to the formation of complicated tertiary structures, in particular if interwoven with metal ions. ${ }^{75,101-103}$ Clearly, we are only beginning to understand the physical and electronic basis for these strategies. In the following sections, we will describe some of the likely mechanisms by which metal ions stimulate catalysis in ribozymes, with the inclusion of precedents from protein enzymes and model systems.

\section{Promoting Catalysis with Charge: Electrostatic Effects}

Stabilizing the charge distribution of the transition state is considered to be one of the most important mechanisms (see Section 2) by which any enzyme promotes chemical reaction. ${ }^{104-107}$ Bound metal ions such as $\mathrm{Mg}^{2+}$ are particularly well-suited for stabilizing anionic transition states because they have a relatively well defined coordination geometry and provide a high charge density. However, such charged species like $\mathrm{Mg}^{2+}$ are not required to make direct contacts to functional groups in the transition state, and they do not need to be in the immediate environment of the active site, in order to exert potent electrostatic effects on catalysis. $\mathrm{Mg}^{2+}$ may simply help to provide charge density to create an electrostatic environment conducive to reaction. Such types of electrostatic contributions can often also be provided by other charged units such as ammonium groups of amino acid side chains or of organic ions. The central role that such charged groups play in catalysis has been established in numerous experimental and theoretical studies on electrostatic 
February 23, 2006; Sigel \& Pyle

effects in protein enzymes. ${ }^{104,106,108-111}$

Many enzymes also use electrostatic effects to indirectly activate functional groups in an active site. In particular, charged groups have been shown to stimulate $\mathrm{p} K_{\mathrm{a}}$ shifts or alter the nucleophilicity of peptide side chains that participate directly in chemical reaction. ${ }^{104,108-110}$ In these cases, it is the localization of a specific charge and its placement in a particular environment, rather than the binding of a metal ion in particular, that is important for function. There are many cases of this in protein enzymes, including those that are commonly considered to be "metal ion-dependent enzymes" and/or "metalloenzymes".

\subsection{Localized Charges Can Modulate the Reactivity of Enzyme Functional Groups}

One of the classic cases in which electrostatic effects, rather than direct contacts, modulate the reactivity of active-site functional groups was observed in acetoacetate decarboxylase. ${ }^{112,113}$ In that enzyme, a lysine side chain forms a Schiff base intermediate during the decarboxylation of acetoacetic acid. Schiff base formation would appear to be a difficult transformation in water because the normal $\mathrm{p} K_{\mathrm{a}}$ of the $\varepsilon-\mathrm{NH}_{3}^{+}$group of lysine is expected to be about 10.5 . However, early kinetic investigations and chemical modification studies indicated that this group in the active site of acetoacetate decarboxylase has a $\mathrm{p} K_{\mathrm{a}}$ of ca. $6 .{ }^{112}$ Based on the reactivity in different ionic strengths and solvents, Kokesh and Westheimer concluded that this remarkable $\mathrm{p} K_{\mathrm{a}}$ shift of 4-5 units was caused by electrostatic effects: ${ }^{112}$ Namely, that the presence of an adjacent positive charge makes protonation of the lysine unfavorable, resulting in a $\mathrm{p} K_{\mathrm{a}}$ shift that generates the reactive primary amine. As precedent, the authors cited the $\mathrm{p} K_{\mathrm{a}}$ values of the adjacent primary amines in ethylenediamine, which are about 7 and 10, respectively. ${ }^{112}$ Subsequent mutational studies on acetoacetate decarboxylase showed that lysine-115, with a $\mathrm{p} K_{\mathrm{a}}$ of 6 , is the nucleophile during Schiff base formation and that its $\mathrm{p} K_{\mathrm{a}}$ is lowered by the positive charge on the adjacent lysine- $116 .{ }^{113}$ Thus, the $\varepsilon$-ammonium group of lysine-116 performs a critical role in catalysis, despite the fact that it does 
not interact directly with any functional group in the active site.

This type of electrostatic induction has been observed in many other protein enzymes. In xylanase from Bacillus circulans, the carboxylate residue of the active-site glutamate-172 serves as a general acid-base catalyst. ${ }^{114}$ This is made possible by a $\mathrm{p} K_{\mathrm{a}}$ shift that raises the $\mathrm{p} K_{\mathrm{a}}$ of the carboxylic-acid side chain of glutamate-172 from 4.2 to 6.7 . The $\mathrm{p} K_{\mathrm{a}}$ shift of this glutamate is caused by the presence of a second ionized glutamate-78 $\left(\mathrm{p} K_{\mathrm{a}}=4.6\right)$ that is used as a catalytic nucleophile during saccharide hydrolysis. ${ }^{114}$ Similar electrostatic effects of neighboring negative charges in combination with hydrophobic environments have been proposed to raise the $\mathrm{p} K_{\mathrm{a}}$ of active-site carboxylic acid groups in phospholipase C from Bacillus cereus $\left(\mathrm{p} K_{\mathrm{a}}=5.3\right)^{115}$ and hen egg-white lysozyme $\left(\mathrm{p} K_{\mathrm{a}}=6.2\right),{ }^{116,117}$ resulting in the promotion of general acid-base catalysis. Thus, depending on the reaction to be catalyzed, localized charges, either positive or negative, in an active site can be used to regulate the $\mathrm{p} K_{\mathrm{a}}$ of potentially reactive functional groups.

Other than serving as proofs of concept, examples such as acetoacetate decarboxylase or lysozyme might seem to be irrelevant to the problem of ribozyme catalysis, where a metal cation would seem unlikely to stimulate catalysis by affecting the charge on an adjacent cationic functionality, because there seem to be so few of the latter. However, there are several circumstances in which electrostatic induction could be promoted by a metal ion. For example, it has been proposed that metal hydroxides or alkoxides can serve as nucleophiles or general bases during the hydrolysis or transesterification of nucleic acids by ribozymes. ${ }^{90,118}$ Indeed, the relatively high nucleophilic capability of metal ion-bound hydroxide is well known ${ }^{119,120}$ and it has been shown to facilitate the hydrolysis of nucleoside 5'-triphosphates. ${ }^{37,49,121,122}$ The formation of a metal hydroxide reduces the charge on the metal ion complex by one unit and it has been suggested that such a cationic charge reduction is highly unfavorable in the negative environment of a nucleic acid. ${ }^{123}$ Thus, the formation of $\mathrm{Mg}\left(\mathrm{H}_{2} \mathrm{O}\right)_{5}(\mathrm{OH})^{+}$is likely to be more favorable if additional divalent metal ions are present in the active site. This may explain the fact that multiple magnesium ions are often required for catalysis in 
protein and RNA enzymes, ${ }^{26,27,29,124}$ as well as for the nonenzymatic hydrolysis of nucleotide triphosphates where two metal ions are needed. ${ }^{37,49,122}$

But perhaps more relevant to the problem of altering nucleic acid $\mathrm{p} K_{\mathrm{a}}$ values is the fact that an adjacent positive charge can cause the formation of a negative charge to become more favorable. This is observed in the $\mathrm{p} K_{\mathrm{a}}$ reductions of serine or cysteine nucleophiles in the families of serine and cysteine proteases ${ }^{125,126}$ and in the formation of the phenolate moiety in acetoacetate decarboxylase. ${ }^{112}$ By analogy, RNA contains two organic functionalities that, with a little help from electrostatic effects, have the potential ${ }^{118}$ to participate directly in either acid-base or nucleophilic catalysis: The guanosine (N1) ${ }^{-}$and uridine $(\mathrm{N} 3)^{-}$groups are normally found to be protonated at neutral $\mathrm{pH}$, with $\mathrm{p} K_{\mathrm{a}}$ values of about 9.2 to $9.5{ }^{42,70}$ But if these $\mathrm{p} K_{\mathrm{a}}$ values were to become lower, then a substantial fraction of these bases would be ionized at neutral $\mathrm{pH}$ (see below), resulting in the respective (N1) ${ }^{-}$and (N3)- anions. Similarly, the $2^{\prime}$ - and 3'-hydroxyl groups of RNA sugars have p $K_{\mathrm{a}}$ values of approximately $12.5 .^{75,127,128}$ Formation of the cognate anions would be stabilized by the presence of divalent cations in the vicinity, even if the metals do not form direct contacts. Indeed, electrostatic stabilization by opposing charges can take place over long distances (Section 4.5). Ample precedent for metal-mediated $\mathrm{p} K_{a}$ shifts in nucleic acids is provided by detailed studies of nucleotide model compounds (Section 4.4), which show that ion binding significantly affects the strength of hydrogen bonds between nucleobases. ${ }^{75,102,129-132}$

\subsection{Electrostatic Induction by Divalent Metal Ions}

Just like charged side chains (Section 4.1), bound metal ions in proteins commonly modulate the $\mathrm{p} K_{\mathrm{a}}$ and the reactivity of adjacent functional groups that participate directly in catalysis. ${ }^{29,133-135}$ Thus, through electrostatic effects, metal ions can play an essential role in catalysis without directly interacting with any substituents in the active site. One of the clearest examples of this effect was observed during studies of GTP hydrolysis by $\mathrm{p} 21$ ras. In that case, the apparent $\mathrm{p} K_{\mathrm{a}}$ of the GTPase 
reaction depends strongly on the metal ion involved. ${ }^{136}$

Although several different reaction mechanisms have been proposed for the metalloenzyme ribonuclease $\mathrm{H}$, two mechanistic features stand out in defining the role of the catalytic metal ion: ${ }^{137} \mathrm{~A}$ critical aspartic acid residue in RNase $\mathrm{H}$ has been proposed to serve as a proton donor during phosphodiester hydrolysis. ${ }^{138}$ Remarkably, this aspartate (Asp-10) undergoes a $\mathrm{p} K_{\mathrm{a}}$ shift of nearly two units (from 6.5 to 4.7 ) upon binding of the $\mathrm{Mg}^{2+}$ cofactor. ${ }^{138}$ Furthermore, it has been shown that the coordinatively saturated cobalt(III) hexammine probe can fulfill the metal ion requirement for this enzyme (Section 5), indicating that the metal ion does not form direct contacts with substituents in the active site. ${ }^{139}$ These two pieces of evidence together suggest that the natural catalytic metal ion in ribonuclease $\mathrm{H}\left(\mathrm{Mg}^{2+}\right)$ may function electrostatically and cause $\mathrm{p} K_{\mathrm{a}}$ shifts in reactive groups.

The cases discussed above involve electrostatic stimulation of general acid-base catalysis. However, the electrostatic influence of metal ions can also serve to alter the $\mathrm{p} K_{\mathrm{a}}$ of nucleophilic groups in metalloenzymes. For example, the catalytic $\mathrm{Zn}^{2+}$ of farnesyl transferase ${ }^{140}$ has been shown to lower the $\mathrm{p} K_{\mathrm{a}}$ of a nucleophilic thiol group by about $2 \mathrm{p} K$ units, to $6.4{ }^{141}$ Interestingly, for bovine liver rhodanese it has been suggested that the positively charged ammonium groups of Arg-186 and Lys-249 assist electrostatically in the deprotonation of the thiol group of Cys-249 in the active site. ${ }^{142}$

\subsection{Switching Charge Types in Proteins: Metals for Lysine and Vice Versa}

Metal ions have unique structural features that can enhance their role in catalysis. For example, metals can provide a geometrically-defined scaffold that helps to organize an active site. However, when a reaction mechanism depends primarily on electrostatic forces, there is little reason to expect that the charges of bound metal ions should behave differently in stimulating catalysis than the localized charges provided by amino acid side chains, bound organic cofactors, or ionized nucleobases. Furthermore, side chains such as the guanidylium group of arginine can mimic the hydrogen bonding and solvation pattern of hydrated metal ions that are essential for catalysis. This is 
underscored by the fact that protein engineering can be used to switch divalent metal ions for positively-charged side chains, and vice versa, in the active sites of metalloenzymes such as EcoRV, BamH1 and ribonuclease $\mathrm{H}$ (regarding further properties and structures of these proteins see, e.g., refs ${ }^{143}$ and ${ }^{29}$, respectively).

The restriction enzymes EcoRV and BamH1 seem to share a common reaction mechanism, i.e., a "two-metal ion mechanism", ${ }^{144,145}$ despite the fact that they do not appear to contain the same number of active-site metal ions. For example, an active-site lysine residue (Lys-92) is essential for EcoRV catalysis. Mutation of Lys-92 to other amino acids results in almost complete abolition of detectable reaction. However, when Lys-92 is mutated to a glutamate, a substantial amount of reactivity is maintained in the presence of $\mathrm{Mn}^{2+} \cdot{ }^{144}$ Thus, it has been proposed that a metal ion (Glu$92 / \mathrm{Mn}^{2+}$ ) can substitute for an ammonium side chain (Lys-92) in the mechanism of EcoRV. ${ }^{144}$ Conversely, it has been shown that Glu- 77 of BamH1 is involved in metal ion binding ${ }^{145}$ and that this residue can be substituted for a lysine without total loss of activity. ${ }^{146}$ The activity of Glu-77/Lys mutants is enhanced in the presence of suppressor mutations that may optimize the positioning of the mutant cationic side chain. ${ }^{147}$ Thus, in both studies ${ }^{144,145}$ the term "two-metal ion mechanism" is used even though EcoRV contains only one metal ion (although replacement of the ammonium side chain of Lys-92 by Glu-92/Mn ${ }^{2+}$ restores activity), ${ }^{144}$ while BamH1 contains two metal ions ${ }^{145}$ (one of which may be replaced by the ammonium side chain of Lys). ${ }^{146,147}$ These results indicate that metal ions and positively charged amino acid side chains can be interchangeable for classes of enzyme that share a common mechanism.

Ribonuclease $\mathrm{H}$ has a strict requirement for divalent cations (Section 4.2), which have been shown to interact through coordinated water molecules (Section 5). Thus, a combination of indirect electrostatic stabilization and hydrogen bonding to the metal ligands have been proposed to play a role in promoting phosphodiester cleavage. ${ }^{139}$ This model for catalysis was supported by protein engineering studies that were guided by the crystal structure of a ribonuclease $\mathrm{H}$ domain, in which a 
bound divalent cation was shown to interact with three acidic side chains. When two of these (Asp and Glu) are mutated to Arg (but not Lys), the double mutant was found to be almost as active as the wild-type enzyme in the absence of divalent cation. ${ }^{148}$ This result underscores the fact that organic functional groups can readily mimic the charge and/or hydrogen-bonding potential of an otherwise essential hydrated metal ion. However, these findings do not imply that, in the native enzyme, metal ions are not intimately involved in catalysis or that enzymes such as ribonuclease H should not be considered metal ion-dependent enzymes. Rather, results of this type suggest that the mechanistic role of divalent cations in these cases is largely of an electrostatic nature.

The hairpin ribozyme has long been known to possess a low level of catalytic activity in the presence of organic cations such as spermidine. ${ }^{149}$ This divalent metal ion-independent activity has been interpreted as the influence of contaminating $\mathrm{Mg}^{2+}$, or as the innate catalytic capability of functional groups on the RNA. ${ }^{15,18}$ It has not, however, been attributed to a catalytic role for the added spermidine. The latter alternative is more credible given recent findings that hairpin ribozyme cleavage can be highly efficient in the presence of aminoglycoside antibiotics or the polyamine spermine. ${ }^{19}$ In some cases, the catalytic activity is the same as that observed with $\mathrm{Mg}^{2+}$. Provided that the organic cation can bind to the ribozyme, the degree of catalytic activity is proportional to the extent to which functional groups are ionized to form positive charges. ${ }^{19}$ These charges may help to structurally organize the active site, and in that sense the primary contribution would be to folding. However, given the fact that cationic cofactors (regardless of their identity) can electrostatically stabilize the anionic transition state, and considering that active-site functional groups may require $\mathrm{p} K_{\mathrm{a}}$ shifts in order to participate in catalysis, multivalent cations may be playing an electrostatic role in promoting chemical catalysis by the hairpin ribozyme.

Interchangeability of metal ions and other types of charged functional groups is observed in even the simple reactions of nucleoside triphosphates. For example, one of the two metal ions needed to activate ATP for hydrolysis may be replaced by $\mathrm{NH}_{4}^{+} \cdot{ }^{150}$ As the interaction between $\mathrm{NH}_{4}^{+}$and 
triphosphate is weaker than that of $\mathrm{Mg}^{2+}$, a smaller stimulation of reaction by $\mathrm{NH}_{4}{ }^{+}$results. However, reactivity can be improved with more highly charged polyaza macrocycles that catalyze facile ATP hydrolysis. $^{151,152}$

\subsection{Electrostatic Induction of $p K_{\mathrm{a}}$ Shifts in Nucleic Acids: Lessons from Nucleobase Model Systems}

It is not surprising that metals and other cations have profound effects on the catalytic properties of ribozymes. After all, work on model systems has shown that bound metal ions dramatically affect the characteristics of their nucleotide constituents. Extensive studies on the effects of metal ion binding to nucleotides and oligonucleotides should now guide our expectations for larger RNA and DNA structures. The $\mathrm{p} K_{\mathrm{a}}$ values of nucleotides other than those of the phosphate groups are more than two log units away in both directions from physiological $\mathrm{pH} .{ }^{67,75,153}$ Nevertheless, many cases of shifted acidities and basicities of nucleobases in nucleic acid structures are known. ${ }^{154-165}$ One way to strongly influence $\mathrm{p} K_{\mathrm{a}}$ values, the geometry, and other fundamental properties of nucleotides are bound metal ions and other fixed charges. ${ }^{66,75,102,153}$ In particular, the effects of metal ions on acidity of nucleotide functional groups has been quantitatively investigated in nucleobase model systems. ${ }^{67,75}$

\subsubsection{Modification of Purine Acidity}

For guanine derivatives it has been established that oxygenation of $\mathrm{C} 8$, methylation of $\mathrm{N} 7$, or direct $\mathrm{N} 7$ coordination by transition metal ions acidifies the $(\mathrm{N} 1) \mathrm{H}$, resulting in $\Delta \mathrm{p} K_{\mathrm{a}}$ values that range from $1.4-2.3$ at that site. ${ }^{42,67,102,166}$ This effect causes (N1)H to be at least partially deprotonated in the physiological $\mathrm{pH}$ region (Figure 2). It is notable that in species composed of multiple nucleobases coordinated to $\mathrm{Pt}^{2+}$, acidifications of $(\mathrm{N} 1) \mathrm{H}$ into the physiological $\mathrm{pH}$ range are achieved. ${ }^{75}$ Even the $\mathrm{p} K_{\mathrm{a}}$ value for $(\mathrm{C} 6) \mathrm{NH}_{2}$ on adenine is strongly perturbed in certain cases of 
multiple coordination. ${ }^{167}$

\section{Figure 2 close to here}

Perhaps more relevant to ribozyme comparisons, $\mathrm{Mg}^{2+}$ binding to guanosine stimulates large changes in acidity, resulting in a $K_{\mathrm{a}}$ value of 8.4 for one of the two (N1)H sites in a GpG dinucleoside monophosphate. ${ }^{42}$ Biophysical and theoretical investigations have established that there are two common modes of interaction between $\mathrm{Mg}^{2+}$ and guanosine N7. While hydrated $\mathrm{Mg}^{2+}$ ions prefer bidentate coordination to guanine $\mathrm{N} 7 /(\mathrm{C} 6) \mathrm{O}$ sites, ${ }^{91,168-170}$ some direct monodentate binding to $\mathrm{N} 7$ of pentahydrated $\mathrm{Mg}^{2+}$ is also known to occur. ${ }^{171-173}$ Both coordination modes are expected to lead to (different) $\mathrm{p} K_{\mathrm{a}}$ shifts, and to be in rapid equilibrium with each other. Thus, it is likely that $\mathrm{Mg}^{2+}$ in proximity to $\mathrm{N} 7$ will significantly perturb the $\mathrm{p} K_{\mathrm{a}}$ of $\mathrm{N} 1$ in numerous contexts. This is consistent with the recent proposal that a (N1)-deprotonated site on an active-site guanosine residue participates in the catalysis by the hairpin ribozyme. ${ }^{118}$

\subsubsection{Modification of Pyrimidine Acidity}

Studies of uridine derivatives suggest that $\mathrm{Mg}^{2+}$ and other alkaline earth ions form semichelates where $\mathrm{M}^{2+}$ is bound by inner-sphere coordination to one of the carbonyl oxygens and by outer-sphere coordination to the deprotonated (N3)- ${ }^{-70}$ This may also result in a shift of the (N3)H $\mathrm{p} K_{\mathrm{a}}$ into the physiological range. Indeed, it has been suggested that two metal ions (including $\mathrm{Mg}^{2+}$, $\mathrm{Mn}^{2+}$ or $\mathrm{Zn}^{2+}$ ) might, with assistance from other binding sites, interact with both carbonyl groups, (C2)O and (C4)O, thereby acidifying (N3)H such that it becomes a proton donor, e.g., in a ribozyme reaction. $^{70}$

Remarkably, in a study of $\mathrm{Zn}^{2+}$-catalyzed cleavage between $\mathrm{C} 3$ and $\mathrm{U} 4$ in the catalytic core of the hammerhead ribozyme, ${ }^{174}$ it was discovered that cleavage of U4 occurs only after a primary cleavage event at A9; i.e., there is a sequential cleavage mechanism. This U4 cleavage is connected with a $\mathrm{pH}$-dependent conformational change and it occurs only at $\mathrm{pH}>7.9$, reaching a maximum at 
February 23, 2006; Sigel \& Pyle

$\mathrm{pH} \sim 8.5 .{ }^{174}$ It has been shown independently that such a conformational change occurs with an apparent $\mathrm{p} K_{\mathrm{a}}$ of about 8.5. ${ }^{175}$ Considering the documented influence of $\mathrm{M}^{2+}$ coordination on $\mathrm{p} K_{\mathrm{a}}$ values for uridine (above) ${ }^{70}$ this behavior is likely to stem from the metal assisted deprotonation of $\mathrm{U} 4$ at (N3).

\subsubsection{Effects on Backbone Functionalities}

It is important to consider the participation of ribose 2'- and 3'-hydroxyl groups as additional sites for metal ion binding. In aqueous solution such interactions are weak ${ }^{176}$ for individual (not deprotonated) hydroxyl groups ( $\mathrm{p} K_{\mathrm{a}} \cong 12.5 ;^{75,127,128,176,177}$ Section 4.1.). However, a study devoted to $\mathrm{Cu}^{2+}$ complexes of adenosine, 2'-deoxyadenosine, uridine, and 2'-deoxyguanosine revealed that the ribose moieties of adenosine and uridine react with $\mathrm{Cu}^{2+}$ to form soluble 1:1 complexes above $\mathrm{pH}$, while the 2'-deoxynucleosides do not react with $\mathrm{Cu}^{2+}$ under the same conditions. ${ }^{178,179}$ The situation is complicated by the proposed formation of hydroxo-bridged dimeric $\mathrm{Cu}^{2+}$ complexes. ${ }^{179}$

Of more relevance for the present context is the observation that simple carbohydrates, which provide three or more hydroxyl groups in specific geometrical arrangements can readily bind $\mathrm{Ca}^{2+} \cdot{ }^{180,181}$ In other words, if a third site were provided by a ribozyme, the 2'- and 3'-hydroxyl groups of ribose might coordinate divalent cations in certain contexts. Indeed, in a crystal structure of $\mathrm{Ca}$ (inosine $5^{\prime}$-monophosphate) $\cdot 6.5 \mathrm{H}_{2} \mathrm{O}$ this binding mode is observed. ${ }^{63,179,182}$

\subsubsection{Additional Reasons for $p K_{a}$ Shifts in Nucleobases}

Although metal ions can cause $\mathrm{p} K_{\mathrm{a}}$ shifts of nucleobase functional groups, there are other mechanisms for this effect that are noteworthy, particularly in ribozymes. One of the most common types of $\mathrm{p} K_{\mathrm{a}}$ shift found in complex RNA structures involves the $\mathrm{N} 1$ moiety of protonated $\mathrm{A}^{+} \cdot \mathrm{C}$ base pairs. ${ }^{154-163}$ There are two such $\mathrm{A}^{+} \cdot \mathrm{C}$ pairs in the extended U6 internal stem loop of spliceosomal RNA, ${ }^{156,158,159}$ and even though they are found in different structural contexts, each has a $\mathrm{p} K_{\mathrm{a}}=6.5$, 
i.e. raised by more than $2 \log$ units. ${ }^{158,159}$ A second example is observed in the VS ribozyme, where a corresponding $\mathrm{A}^{+} \cdot \mathrm{C}$ pair is located one base pair downstream from the cleavage site. ${ }^{160,161}$ In both the spliceosome and the VS ribozyme, these positively charged $\mathrm{A}^{+} \cdot \mathrm{C}$ base pairs are likely to play an important role in catalysis.

Finally, it is important to note that two equivalent, consecutive nucleotides in a single stranded region will show perturbed $\mathrm{p} K_{\mathrm{a}}$ values. Whenever two equivalent (de)protonation sites are present in one molecule, one of the $\mathrm{p} K_{\mathrm{a}}$ values will be lowered by $0.3 \log$ units whereas the second one will be raised by the same amount, simply due to statistical effects. ${ }^{65,183,184}$

\subsubsection{Water-Hydroxide Equilibria and the "Metal Ion Switch Experiment"}

In the context of metal-stimulated acidifications, it is important to consider implications for common "metal ion specificity switch experiments" or thio-rescue studies that have become so prevalent in ribozyme enzymology. ${ }^{12}$ It is worth noting that sulfur binding in $\mathrm{Zn}^{2+}$ complexes of adenosine $5^{\prime}-O$-thiomonophosphate $\left(\mathrm{AMPS}^{2-}\right)^{185}$ or methyl thiophosphate (MeOPS $\left.{ }^{2-}\right)^{186}$ leads to an acidification of $\mathrm{Zn}^{2+}$-bound water molecules. For example, the deprotonation of a coordinated water molecule in $\mathrm{Zn}(\mathrm{MeOPS})(\mathrm{aq})$ leading to $\mathrm{Zn}(\mathrm{MeOPS})(\mathrm{OH})^{-}$formation ${ }^{186}$ has a $\mathrm{p} K_{\mathrm{a}}=6.9 \pm 0.2$. This is a considerable shift from the normal $\mathrm{p} K_{\mathrm{a}}$ of $\cong 9$ for $\mathrm{Zn}(\mathrm{aq})^{2+} \cdot{ }^{177}$ This increased acidity due to coordinated phosphorothioates is attributed to a reduction of the $\mathrm{Zn}^{2+}$ coordination number from 6 to 4. ${ }^{185}$ This effect is also observed in other instances, e.g., with imidazole as ligand. ${ }^{177}$ The formation of fourfold-coordinate $\mathrm{Zn}^{2+}$ is apparently driven by the Lewis basicity of the donor atoms. ${ }^{177}$ However, a reduction to coordination number 5 also exerts a significant effect. ${ }^{177}$ In cases where amino groups are provided in the second coordination sphere of $\mathrm{Zn}^{2+}$ (thereby facilitating formation of hydrogen bonds), ${ }^{187}$ the formation of the hydroxo complex is further facilitated.

Although it is not known if this reduction in coordination sphere occurs upon $\mathrm{Zn}^{2+}$ coordination to thio-substituted ribozymes, the possibility should certainly be kept in mind. Hydroxide formation 
within the coordination sphere of $\mathrm{Mg}^{2+}$ is also believed to reduce the coordination number. ${ }^{188}$ Related issues regarding the use of $\mathrm{Mn}^{2+}$ in rescue experiments have recently been indicated in different contexts. ${ }^{13,185,186,189}$

\subsection{The Distance-Dependence and Additivity of Charge Effects}

Having established that the electrostatic effects of localized charges can strongly influence catalysis, ${ }^{106}$ it is interesting to consider the importance of proximity. Studies on a wide range of biochemical phenomena including enzymatic catalysis, ${ }^{190-192}$ protein folding, ${ }^{193}$ redox behavior, ${ }^{194}$ and ligand binding ${ }^{195}$ have shown that charged groups can be quite far from the functional groups they influence. But this raises another question: How close do they need to be? This question has been addressed through meticulous studies of long-range electrostatic effects which have been conducted through protein engineering studies and theoretical analyses of the enzyme subtilisin. ${ }^{196,197}$

Subtilisin catalyzes proteolysis using an active-site histidine (His-64) as a general base. The efficiency of the reaction is directly related to the $\mathrm{p} K_{\mathrm{a}}$ of this histidine group. When charged functional groups (Asp or Glu) on the surface of the protein are mutated to neutral residues (Ser), the $\mathrm{p} K_{\mathrm{a}}$ of His-64 shifts downwards by $0.4 \mathrm{pH}$ units. ${ }^{196}$ The magnitude of this $\mathrm{p} K_{\mathrm{a}}$ shift increases as more surface residues are mutated, suggesting that long-range electrostatic effects are additive to some extent. ${ }^{192}$ Charged surface residues about $15 \AA$ away from the imidazole of His-64 in subtilisin indicate that localized charges far from an active site can exert a significant effect on catalytic groups (Figure 3). ${ }^{197}$

\section{Figure 3 close to here}

Other enzymatic functions of subtilisin are also affected by long-range electrostatic effects of surface residues. For example, substrate specificity is altered by more than 100 -fold when two surface charges are mutated on subtilisin. ${ }^{192}$ Furthermore, studies of enzyme inhibitors suggest that the charge distribution of the transition state is also influenced by long-range electrostatic effects. ${ }^{197}$ 
The relationship between distance and electrostatic effects on catalysis is complicated and difficult to predict using simple approximations. The influence of a charge depends on its position in the macromolecule, on the solvent and counterion accessibility, and on the shape of the molecule itself. ${ }^{198}$ Despite these complexities, the influence of localized charges has been successfully modeled with computational methods that account for more complex molecular features. ${ }^{111,199,200}$ Studies using the finite difference Poisson-Boltzmann method have shown that the electrostatic field effects of charged amino acids on the surface of the enzyme contribute to the reactivity of actinidin, papain, trypsin, and lysozyme. ${ }^{190}$ In the latter case, it was suggested that a cluster of positive charges in one section of the protein serves to focus electric field lines through the active site. ${ }^{201}$

In terms of ribozymes, these results suggest that catalytically important metal ions or other cations need not be bound precisely at the site where catalysis occurs. Thus, the lack of a metal ion specificity switch for phosphoryl or ribose oxygens at a scissile linkage does not imply that metal ions (or other cations) are not essential for catalysis. Furthermore, there may be examples in which catalytically important metal ions bind far from an apparent site of ribozyme catalysis. This type of scenario may already be playing out in studies of two small ribozymes, the hairpin and the hammerhead ribozyme. The recently solved crystal structure of the hairpin ribozyme shows no divalent metal ion at the catalytic site, but instead six $\mathrm{Ca}^{2+}$ ions are located between 13-16 $\AA$ from the cleavable phosphodiester bond (Figures $3 \mathrm{~b}$ and 4 ). ${ }^{202}$ Four of the $\mathrm{Ca}^{2+}$ ions are located in the major groove, two of those positions being very well defined. ${ }^{202}$ Taken together, these six divalent

\section{Figure 4 close to here}

metal ions are likely to strongly electrostatically stabilize the anionic transition state from a distance, in a manner similar to that observed in proteins (e.g. in RNAse A, see also legend to Figure 4a). In case of the hammerhead ribozyme, metal switch studies and kinetic analyses indicate that a catalytically important $\mathrm{Mg}^{2+}$ is bound to the phosphoryl oxygen at position G5, which is a site that is about $10 \AA$ away from the expected location of the cleavage site as determined from multiple crystal 
structures of the hammerhead ribozyme. ${ }^{203-205}$ This has led to suggestions that the crystal structure does not represent the active conformation, or that the chemical mechanism does not involve the metal ion that is bound at site G5. However, there is one mechanism that is consistent with all the data that has been reported: The catalytically essential metal ion in the hammerhead ribozyme may influence reaction through long-range electrostatic effects.

\section{Metal lon Catalysis through Outersphere Interactions}

Many different enzymes catalyze the activation of carbonyl or phosphoryl moieties in the presence of divalent metal ions. It has long been known that these metals (usually $\mathrm{Zn}^{2+}, \mathrm{Mg}^{2+}$ or $\mathrm{Mn}^{2+}$ ) participate in electrostatic catalysis (in some instances more specifically termed electrophilic catalysis), by helping to polarize carbonyl or phosphoryl groups and stabilizing the buildup of charge on oxygen. ${ }^{107}$ Although it was generally believed that the metal ion interacts directly with the oxygen in these enzymes, there are now examples in which the metal ion participates in its fully hydrated form, through "outersphere" or ligand-mediated interactions.

For example, direct evidence for catalytic activation via outersphere interactions of metal ions came from studies of ribonuclease H. In that case, it was shown that coordinatively saturated, substitutionally inert metal complexes such as cobalt(III) hexammine $\left(\mathrm{Co}\left(\mathrm{NH}_{3}\right)_{6}^{3+}\right)$ could fully satisfy the requirement for $\mathrm{Mg}^{2+} \cdot{ }^{139}$ This indicated that $\mathrm{Mg}\left(\mathrm{H}_{2} \mathrm{O}\right)_{6}^{2+}$ was the catalytically active form of the divalent cation in ribonuclease $\mathrm{H}$ and that a metal ion could play a critical role in catalysis without forming innersphere (direct) contacts to atoms of the enzyme or substrate. ${ }^{139}$ Similarly, inert chromium(III) complexes were used to show that the metal ion cofactor of $E$. coli exonuclease III uses outersphere contacts to potentiate catalysis. ${ }^{206}$ Together with protein engineering studies on ribonuclease $\mathrm{H}$ (showing that the hydrated metal ion could be replaced by two arginine residues), ${ }^{148}$ all of these studies support the view that direct interactions are not required a priori: Metal ions can activate substrates at a distance through electrostatic effects and coordinated water molecules! 
There is now ample precedent for this effect in ribozymes. One of the first indications that metal ions participated indirectly in reactions of the hairpin ribozyme was that $\mathrm{Co}\left(\mathrm{NH}_{3}\right)_{6}^{3+}$ was found to fully substitute for $\mathrm{Mg}^{2+} \cdot{ }^{15,16}$ While this was interpreted as a structural role for the metal ion, it can also be interpreted in the same way as studies of ribonuclease $\mathrm{H}$, by invoking electrostatic and/or solvent interactions. Recently, it has been observed that natural ribozymes and those derived through in vitro selection can catalyze a variety of new chemistries that differ dramatically from the phosphoryl transfer and hydrolysis reactions that have been previously characterized. ${ }^{8,9,207-211}$ For example, an acyl transferase ribozyme was recently selected for the ability to form ester and amidelinked products. ${ }^{212}$ This ribozyme was found to be dependent on the presence of divalent metal ions, but a thorough analysis of the metal ion requirements revealed that cobalt(III) hexammine also helped promote efficient catalysis. ${ }^{20}$ This finding, together with an analysis of the $\mathrm{Mg}^{2+}$-dependence of the reaction showed that the metal ion cofactor in this ribozyme interacts through an outersphere mechanism and that $\mathrm{Mg}^{2+}$ participates in catalysis in its fully hydrated form $\left(\mathrm{Mg}\left(\mathrm{H}_{2} \mathrm{O}\right)_{6}^{2+}\right){ }^{20}$

Structural studies of metal ion binding in RNA have now shown that divalent metal ions form intimate interactions with RNA through outersphere coordination. ${ }^{11,13,14,48,92,170,213,214}$ These complexes tend to form in the deep and narrow major groove, which has a geometry that is wellsuited for the formation of outersphere interactions between metal ligands and the nucleobase and backbone functionalities of the helix. Tandem G-U wobble pairs in particular are common for $\mathrm{Mg}\left(\mathrm{H}_{2} \mathrm{O}\right)_{6}^{2+}$ binding at N7/(C6)O sites, ${ }^{91,170,213,215,216}$ perhaps because of the high density of hydrogen-bond acceptors that cluster in the major groove of this motif. The interaction of hydrated metal ions with the major groove of RNA is highly favorable electrostatically, ${ }^{217,218}$ as the potential in the major groove has been found to be the most negative region of an RNA duplex ( -15 to -20 $\mathrm{kT}) .{ }^{218}$ In more complex structures, the electrostatic potential of other motifs has been found to be extraordinarily negative (up to $-100 \mathrm{kT}$ ) and metal ions tend to interact strongly with these sites 
through both inner- and outersphere mechanisms. ${ }^{218}$

It is important to note that $\mathrm{Mg}^{2+}$ has a pronounced tendency to interact with $\mathrm{N}$-donor sites through outer-sphere interactions. ${ }^{71,77}$ This has been established for N7 of guanine, ${ }^{42,91,92,170,219}$ the $\mathrm{N} 3$ of cytosine, ${ }^{68}$ and (N3) ${ }^{-}$of uracil. ${ }^{70}$ The properties of $\mathrm{Ca}^{2+}$ are very similar in this respect, ${ }^{68,70,71,77,219}$ and both metal ions have been observed to interact with carbonyl groups in an outer- or innersphere manner. ${ }^{70}$ Interestingly, in a decamer oligonucleotide $\mathrm{Mg}\left(\mathrm{H}_{2} \mathrm{O}\right)_{6}^{2+}$ binds the edges of two adjacent guanines at the N7 and (C6)O sites through water-mediated hydrogen bonds. ${ }^{91}$ There are always exceptions to the rule: In a $\mathrm{Ca}^{2+}$ form of a B-DNA decamer, the metal ion binds through innersphere coordination to adjacent N7 and C(6)O atoms of GG bases. ${ }^{219}$ However, in the same study it was shown that most interactions of $\mathrm{Mg}^{2+}$ and $\mathrm{Ca}^{2+}$ occur via outersphere interactions with $\mathrm{N} 7$ and (C6)O atoms from either one or adjacent guanosines. ${ }^{219}$ Of course, the $3 \mathrm{~d}$ metal ions $\mathrm{Mn}^{2+}$ (cf. $\left.{ }^{220}\right), \mathrm{Co}^{2+}\left(\mathrm{cf.}^{221}\right), \mathrm{Ni}^{2+}\left(\mathrm{cf}^{221,222}\right.$ ) or $\mathrm{Zn}^{2+}$ (cf. ${ }^{221}$ ) prefer to form inner-sphere coordination with N7 sites, though in aqueous solution there may be intramolecular equilibria between innersphere and outersphere species as shown with $\mathrm{M}(\mathrm{ATP})^{2-}$ complexes. $^{223}$

Among the exchange-labile metal ions, $\mathrm{Mg}^{2+}$ is especially suited for outersphere interactions. This is clear from the determination of so-called 'apparent dynamic hydration numbers' (ADHN), which were determined via apparent molecular weights on Sephadex columns. ${ }^{224}$ Hexacoordinate $\mathrm{Mg}^{2+}$ and $\mathrm{Zn}^{2+}$ have $\mathrm{ADHN}$ values of 5.85 and 2.18 , respectively. This indicates that $\mathrm{Mg}^{2+}$ has nearly six tightly bound water molecules in its first hydration layer, whereas $\mathrm{Zn}^{2+}$ averages two water molecules out of six coordination sites. Ten-coordinate $\mathrm{Ca}^{2+}$ has an ADHN value of $2.38,{ }^{224}$ which indicates that $\mathrm{Ca}^{2+}$ readily loses innersphere water molecules. These analyses are in accord with the very large solvation energy of $\mathrm{Mg}^{2+}$ and also with the relatively slow substitution rate for water in the first coordination sphere of $\mathrm{Mg}\left(\mathrm{H}_{2} \mathrm{O}\right)_{\mathrm{n}}^{2+} \cdot{ }^{225}$ The water exchange rate in hydrated $\mathrm{Mg}^{2+}$ is slower by a factor of $10^{3}$ relative to $\mathrm{Ca}^{2+}$ and by a factor of nearly $10^{2}$ by comparison with $\mathrm{Mn}^{2+}$ or $\mathrm{Zn}^{2+}$. 25 This 
does not imply that $\mathrm{Mg}^{2+}$ is an inert metal ion; its water-exchange rate in the first coordination sphere is still $10^{9}$ faster than that of $\mathrm{Pt}^{2+}$. But among the above-mentioned biologically relevant metal ions, $\mathrm{Mg}^{2+}$ has by far the slowest water exchange rate.

\section{Catalysis by Monovalent Metal Ions}

In the preceding sections, we have discussed mechanisms by which divalent cations can contribute to catalysis without forming direct, innersphere contacts that are critical for reaction. The examples show that it is often the charge of the metal ion, and in some cases, the surrounding solvent ligands, that are important for function. Given these mechanisms and the fact that metal ions can sometimes be substituted by positively charged amino acid side-chains, it is not surprising that catalytic divalent metal ions can be functionally substituted by monovalent ions in certain cases and that monovalent ions can often be found in the native structure.

There are many protein enzymes that utilize monovalent ions specifically for catalysis. The first case of this was provided by pyruvate kinase, which requires $\mathrm{K}^{+},{ }^{226,227}$ and it was subsequently determined that there are numerous additional examples. ${ }^{228,229,230}$ A recent compilation of monovalent-stimulated enzymes has nearly 60 entries, ${ }^{231}$ which fall into two distinct classes. The first and largest class consists of enzymes that are activated by $\mathrm{K}^{+} \cdot{ }^{231}$ These enzymes are also often active with $\mathrm{NH}_{4}^{+}$or $\mathrm{Rb}^{+}$, but they are frequently inhibited by $\mathrm{Na}^{+}$or $\mathrm{Li}^{+}$. The second class contains enzymes that are activated by $\mathrm{Na}^{+}$. These are also usually active with $\mathrm{Li}^{+}$but inhibited by $\mathrm{K}^{+}, \mathrm{NH}_{4}^{+}$or $\mathrm{Rb}^{+} \cdot{ }^{229,230}$ The mutually exclusive ion choices of these two enzyme classes suggest that ionic size is a major determinant for function, although recent crystallographic studies also highlight differences in coordination environment. ${ }^{232}$ In fact, depending on this environment, the coordination number (CN) for $\mathrm{Na}^{+}$and $\mathrm{K}^{+}$may vary between 4 and 12 , and this strongly affects ionic radii. For $\mathrm{Na}^{+}$, the limiting values are $1.13 \AA(\mathrm{CN}=4)$ and $1.53 \AA(12)$, and for $\mathrm{K}^{+}$, they are $1.51 \AA(4)$ and $1.78 \AA(12) .^{231}$ 
Dialkylglycine decarboxylase belongs to the $\alpha$ family of pyridoxal-phosphate-dependent enzymes. This enzyme is activated by $\mathrm{K}^{+}$and inhibited by $\mathrm{Na}^{+}$or $\mathrm{Li}^{+} \cdot{ }^{231}$ Crystallographic analysis of the active site shows that the $\mathrm{K}^{+}$cofactor adopts an octahedral coordination geometry (Figure 5),

\section{Figure 5 close to here}

which degenerates to a distorted trigonal bipyramid when $\mathrm{K}^{+}$is switched with the inhibitory $\mathrm{Na}^{+}$ ion. ${ }^{232}$ Given the preceding discussion of electrostatic induction at a distance (Section 4.5), it is notable that the $\mathrm{K}^{+}$ion in dialkylglycine decarboxylase is located $11 \AA$ from the aldimine nitrogen that it helps to activate.

The "organizing power" of monovalent metal ions is quite high and this is evident from studies of low-molecular-weight complexes, e.g. with nucleotides. For example, the addition of $\mathrm{MCl}$ (with $\left.\mathrm{M}^{+}=\mathrm{Na}^{+}, \mathrm{K}^{+}, \mathrm{Rb}^{+}, \mathrm{NH}_{4}{ }^{+}\right)$to an aqueous solution of $\mathrm{Na}_{2}\left(5^{\prime}-\mathrm{GMP}\right) \cdot \mathrm{H}_{2} \mathrm{O}$ results in higher order gellike structures that consist of guanine quartets stabilized by ions on the quadruplex surface and along interior channels, where sodium ions are coordinated to carbonyl oxygens. ${ }^{233}$ Related studies have been carried out with $\mathrm{Na}^{+}, \mathrm{K}^{+}, \mathrm{Rb}^{+}$, and $\mathrm{Cs}^{+}$in complex with the nucleobase models 1-methylthymine and 1-ethylthymine. ${ }^{234}$ In these cases, one observes outersphere binding, e.g., in a $\mathrm{Na}^{+}$thymine quartet, but also innersphere coordination occurs involving $(\mathrm{C} 2) \mathrm{O}$ and $(\mathrm{C} 4) \mathrm{O}$, e.g., in a $\mathrm{K}^{+}$quartet. A $\mathrm{Na}^{+}$-induced uracil quartet has also been isolated and structurally characterized by X-ray and NMR spectroscopy. ${ }^{235,236}$ That monovalent ions are also able to promote simple reactions in nucleic acid models has been proven in studies of the metal ion-facilitated hydrolysis of ATP: ${ }^{150}$ One of the two divalent metal ions required for coordination to the triphosphate chain and subsequent phosphoanhydride cleavage can be replaced by $\mathrm{Na}^{+}$. For example, in the $\mathrm{Zn}^{2+} / \mathrm{ATP}$ system at $\mathrm{pH} 7.5$, when the $\mathrm{Na}^{+}$concentration is increased from 0.1 to $1 \mathrm{M}$, the reaction rate for hydrolysis increases by a factor of 2.7 .

That monovalent ions can organize three-dimensional structures and promote catalysis in larger nucleic acid assemblies has been demonstrated by studies of tRNA, RNA in general, ribozymes, as 
well as DNA. ${ }^{18,90,92,214,237-245}$ It has been challenging to identify these monovalent sites through crystallographic analysis because of the difficulty in distinguishing (partially occupied) $\mathrm{K}^{+}$and $\mathrm{Na}^{+}$ from water molecules. ${ }^{246}$ For investigations of specific potassium sites, heavy atom thallium or cesium substitutions have been extremely useful. These were instrumental in detecting a specific $\mathrm{K}^{+}$ binding site in the "tetraloop-receptor motif", which is a ubiquitous element of RNA tertiary structure. ${ }^{240}$ Potassium at this site was examined using a combination of crystallographic and chemogenetic methodologies that employed thallium substitution. ${ }^{240,247}$ Recent crystallographic analyses of the large group I intron ribozymes establish that $\mathrm{K}^{+}$can bind to the exact site that is normally occupied by a catalytic $\mathrm{Mg}^{2+}$ in the catalytic center of that ribozyme. In the first crystal structure of an intact group I intron (which catalyzes transesterification using a two-metal ion mechanism), one of the two catalytic metal binding sites was occupied by $\mathrm{K}^{+}$(Figure 6). ${ }^{90}$ More recent structures of the same intron show that $\mathrm{Mg}^{2+}$ binds (and is probably the functional ion) at this same site (Figure 6). ${ }^{248}$

\section{Figure 6 close to here}

Sodium sites have been particularly difficult to elucidate because the X-ray scattering contributions of water are virtually identical to those of $\mathrm{Na}^{+}$, and because $\mathrm{Na}^{+} \cdots \mathrm{O}$ distances are only slightly shorter than strong hydrogen bonds. ${ }^{246}$ Nonetheless, it was possible to resolve $\mathrm{Na}^{+}$ions in high resolution structures of a DNA Holliday junction, where two hydrated $\mathrm{Na}^{+}$ions stabilize a network of ordered hydration that is found inside the junction arms. ${ }^{249}$ Other examples of specific monovalent ion binding sites include telomeric DNA quartet structures ${ }^{233,234,250-252}$ and certain RNA pseudoknots that require specific monovalent ions for folding. ${ }^{243,253}$

Taken together, the effects of monovalent ions on protein enzymes and nucleic acid model systems are particularly important in light of the fact that the hairpin, hammerhead, and VS ribozymes are known to react at molar concentrations of monovalent ion (such as $\mathrm{Li}^{+}$or $\left.^{+}{ }^{+}\right) .{ }^{18,241,242}$ These findings have been interpreted to mean that these ribozymes require metal ions only for 
structural purposes and there is no role for metal ions (and specifically no role for $\mathrm{Mg}^{2+}$ ) in chemical catalysis. Given the precedent set by other systems, it is necessary to reconsider this interpretation. The high concentration of metal ion required for the hairpin, hammerhead and VS ribozymes suggests that they do not contain specific sites for the binding of alkali metal ions. Rather, it is important to consider that molar concentrations of $\mathrm{NaCl}$ readily substitute for millimolar amounts of $\mathrm{MgCl}_{2}$ (the concentration typically used in the study of these ribozymes) during tertiary structure formation. ${ }^{254}$ Thermodynamic and chemical probing studies have established that similar RNA structures can form in $10 \mathrm{mM} \mathrm{Mg}^{2+}$ and $1 \mathrm{M} \mathrm{Na}^{+} .254$ This is why nearest-neighbor calculations that are commonly used for RNA structure prediction (and which were measured at $1 \mathrm{M} \mathrm{Na}^{+}$) are valid for approximating the stabilities of RNA molecules at millimolar concentrations of $\mathrm{Mg}^{2+}$. The activity of ribozymes in molar concentrations of monovalent ion may therefore be due to the fact that, at sufficiently high concentrations, monovalent ions can occupy active-site regions that normally contain $\mathrm{Mg}^{2+}$. The feasibility of this interchangeability is underscored by the various structures of the aforementioned Azoarcus group I intron. ${ }^{90,248}$ Indeed, stability constant comparisons of complexes ${ }^{255}$ formed between nucleoside monophosphates or nucleoside diphosphates and $\mathrm{Na}^{+} / \mathrm{K}^{+}$on the one hand and $\mathrm{Mg}^{2+}$ on the other indicate that the stability difference amounts roughly to a factor of 100 . This stability enhancement corresponds well with the empirically-determined parity of $1 \mathrm{M}\left(\mathrm{Na}^{+}\right)$versus $0.01 \mathrm{M}\left(\mathrm{Mg}^{2+}\right)$ conditions used in studies of nucleic acid structure.

Studies with model compounds, protein enzymes and folded RNA molecules are all consistent with the same interpretation: monovalent cations can specifically promote structural assembly and macromolecular catalysis. Furthermore, at sufficiently high concentrations, they can occupy and functionally subsitute at sites that are normally occupied by divalent cations. Therefore, the detection of ribozyme catalysis at high concentrations of monovalent cation does not contraindicate a central role for divalent cations in the chemical mechanism of a particular ribozyme. Rather, ribozyme activation at high monovalent concentrations is fully consistent with the expected behavior of 
catalysts that are divalent ion dependent under physiological conditions.

\section{A Reduced Solvent Polarity Promotes Reactivity}

A final point that needs to be considered is that all types of electrostatic interactions are enhanced by a decreasing permitivity and therefore phosphoryl transfer reactions of the kind fascilited by ribozymes, and as discussed in the preceding sections, are exspected to be also strongly promoted by an environment of reduced polarity. This phenomenon has been extensively investigated with model systems, e.g., with the $\mathrm{Zn}^{2+} / \mathrm{ATP} / \mathrm{Mg}^{2+}$ system at $\mathrm{pH} 7.5$ in water and in water containing 30\% (v/v) 1,4-dioxane; the observed rate enhancement for ATP hydrolysis in the latter case is a remarkable factor of $\sim 70 .^{150}$ This result is mentioned here because it has been concluded with regard to proteins that "the unit positive charge of sodium and potassium ions can ... attain greater potency in regions of low dielectric constant". 231

The dielectric constant of bulk water is close to 80 . Based on theoretical considerations intrinsic dielectric constants (permittivities) in proteins have been calculated to be, e.g., 2 (cf. ${ }^{199}$ ), 10 (cf. ${ }^{138}$ ), and 15-25 (cf. ${ }^{256}$ ) depending on the model and the protein considered. Experimental studies, based on acid-base or redox properties, have led to so-called equivalent-solution or effective dielectric constants for the active-site cavities of carbonic anhydrase and carboxypeptidase A as being 35 and $<70$, respectively. ${ }^{257,258}$ For cytochrome $c_{551}$ a value of 27 is given for the region between the heme iron and a propionate residue; the charged groups are buried at least $5 \AA$ beneath the protein surface. ${ }^{194}$ For a similar situation in ferricytochrome $c$ an effective dielectric constant of about 50 was estimated. ${ }^{259}$

It has been shown that a decreased solvent polarity exists on the surface of proteins ${ }^{260,261}$ as well as in active-site cavities. ${ }^{257,258}$ In addition, there is evidence for cooperative effects between hydrophobic and polar interactions involving hydrogen bonding. ${ }^{262,263}$ Such effects lead to a reduced activity of water in proteins. ${ }^{261}$ Structured water is well known to ccur in nucleic acids, ${ }^{264-268}$ and is 
exspected to give rise to a reduced permittivity. Hence, one may assume that in ribozymes there are sites where the effective dielectric constants are on the order of 30 to 50 . Such a reduced effective dielectric constant will not only influence the strength of binding but also the binding mode, as a low dielectric medium favors innersphere binding of ligands to metal ions. ${ }^{269}$

Indeed, with organic solvent mixtures one may attempt to simulate situations of this kind. For example, water containing $40 \%(\mathrm{v} / \mathrm{v})$ 1,4-dioxane (this corresponds to a mole fraction of 0.124$)$ has a dielectric constant of about 44 , compared to nearly 80 of water. ${ }^{270}$ However, the stability constant of the complex formed between $\mathrm{Cu}^{2+}$ and D-ribose 5-monophosphate has increased from $\log K_{\text {stab }}=$ 2.96 in water to a value of 4.09 in this solvent mixture. ${ }^{270}$ In other words, the $\mathrm{Cu}^{2+}$-phosphate interaction is enhanced by a factor of more than 10 by this simple change in medium. This result also holds for other metal ions and other phosphate or carboxylate ligands. ${ }^{270,271}$ Perhaps more important under such conditions of a reduced solvent polarity, hydroxyl groups and carbonyl oxygens, which do not participate in metal ion binding in aqueous solution, ${ }^{272}$ or only very weakly, ${ }^{273}$ are likely to

coordinate effectively and to participate in chelate formation. ${ }^{272,273}$ Clearly, with regard to ribozymes and especially the binding of monovalent metal ions in buried sites, these observations are of relevance.

\section{Conclusions}

It is essential to revise conventional views of ribozyme catalysis in light of our knowledge about the functional role of metal ions in protein enzymes, model systems, and within folded RNA structures. Specifically, it is vital to broaden our definition of metal ion-assisted catalysis if we are to understand the biochemical function of ribozymes, particularly under physiological conditions. It is clear that divalent metal ions can play an essential role in the chemical mechanism of ribozyme catalysis through several pathways (and not limited to these):

a. Direct coordination of divalent ions to functional groups in the transition state for 
February 23, 2006; Sigel \& Pyle

stabilization of transition-state geometry and charge neutralization.

b. Outer-sphere coordination of divalent metal ions that play an obligate role in electrostatic and structural stabilization of the transition-state.

c. Long-range electrostatic stabilization of transition-state charge by distant metal ions.

d. Stimulation of nucleotide $\mathrm{p} K_{\mathrm{a}}$ shifts, resulting in nucleobase or sugar activation for participation in electrostatic, general acid-base and other forms of catalysis.

Given the molecular mechanism of the latter three cases, there will be conditions under which other types of cation will functionally substitute for the divalent ion (including monovalents, organic polyamines or coordinatively saturated metal complexes). However, this substitutional flexibility is to be expected and should not disqualify a macromolecule from being considered a metalloenzyme under optimal or biologically relevant conditions. Just as certain protein metalloenzymes can substitute alternative cationic moieties for "catalytic" metal ions, the same is likely to be true for ribozymes. It is also important to consider the ability of monovalent ions, and of the potassium ion in particular, to directly support catalytic function. Magnesium $(1-2 \mathrm{mM})$ and potassium $(\sim 100 \mathrm{mM})$ are the most abundant cellular metal ions and it is therefore likely that ribozymes have been optimized to employ them.

The notion that ribozymes are all obligate metalloenzymes has fallen out of favor, and this is probably a good thing because it is an oversimplification that belies the complexity and diversity of ribozyme mechanism. It is likely that there are ribozymes for which metal ions play no catalytic role whatsoever. However, if one adopts a broader (and chemically more realistic) perspective on the mechanisms by which metal ions stimulate catalysis, we may find that most ribozymes are, in fact, metalloenzymes.

\section{Acknowledgments}

We thank Michèle C. Erat, Olga Fedorova, Janet Morrow, Michael Roitzsch, and Helmut Sigel 
February 23, 2006; Sigel \& Pyle

for helpful suggestions and comments on the manuscript. We thank the Swiss National Science

Foundation (SNF-Förderungsprofessur to R.K.O.S., PP002-68733/1) and the U.S. National Institutes of Health (A.M.P.) for financial support (GM50313). A.M.P. is a Howard Hughes Medical Institute investigator. 


\section{Figure Captions}

Figure 1. Metal ion-binding sites in proteins and RNA. (a) Out of twenty amino acids, only cystein, aspartic acid, glutamic acid and histidine compose the majority of all metal ion binding sites in metalloproteins. Shown are the side chains and in case of cystein also the peptide backbone. The coordinating atoms are indicated in red. Please note that the thiol group of cysteine is deprotonated when bound to a metal. (b) In case of RNA (and also DNA) all four different nucleotides provide several donor atoms each for metal ion coordination, as indicated in red. Please note that in addition also the bridging oxygen atoms of the phosphates, the N3 position of purines as well as deprotonated gua- $\mathrm{N}^{-}$and ura- $\mathrm{N}^{-}$can act as coordination sites (indicated in blue).

Figure 2. Shifted $\mathrm{p} K_{\mathrm{a}}$ values of nucleobases. The $\mathrm{N} 1 \mathrm{H}$ of the guanine moiety is strongly acidified by either metallation of the $\mathrm{N} 7$ position, as in $[\operatorname{dienPt}(9 \text {-ethylguanine })]^{2+}\left(\Delta, \mathrm{p} K_{\mathrm{a}}=8.14 \pm 0.06\right)$, or by methylation, as in 7,9-dimethylguanine $\left(\bullet, \mathrm{p} K_{\mathrm{a}}=7.27 \pm 0.01\right)$, when compared to the simple 9ethylguanine moiety $\left(\mathbf{m}, \mathrm{p} K_{\mathrm{a}}=9.54 \pm 0.08\right)$. The extents of acidification, $\Delta \mathrm{p} K_{\mathrm{a}}$, are indicated. All error limits given correspond to three times the standard deviation. The experimental data shown correspond to the ${ }^{1} \mathrm{H}$ chemical shift changes dependent on $\mathrm{pH}$ and normalized to the protonation degree for each substance. In case of the two 9-ethylguanine compounds, the chemical shift of H8 and in case of 7,9-dimethylguanine of the methyl group at N7 are evaluated. ${ }^{102,166}$

Figure 3. Distance effect of charges. (a) Shown is a part of the three-dimensional structure of subtilisin, which is a protease using an active site histidine (His64) as a general base. The charged residues Asp36 and Asp99 on the surface of the protein finetune the $\mathrm{p} K_{\mathrm{a}}$ of His64 from a distance of 13-15 $\AA .{ }^{197}$ This panel has been prepared using WebLab Viewer Lite and the coordinates 2ST1. ${ }^{274}$ (b) The active site of the hairpin ribozyme in the initiation state shows at least $\mathrm{Ca}^{2+}$ ions (five of 
which are depicted; green spheres and arrows) in a distance between 12 and $18 \AA$ from the cleavable phosphodiester bridge (in yellow, flanked be G-1 and A+1). A38 is presumed to be protonated at N1 to stabilize the leaving group (see also Figure 4). ${ }^{275,276}$ This panel has been prepared with MOLMOL ${ }^{277}$ based on the coordinates $1 \mathrm{M} 5 \mathrm{~K} .^{202}$

Figure 4. Negative (red) and positive (blue) charges at the active site of RNAse A and the hairpin ribozyme during the transition state of RNA cleavage. (a) The two negative charges of the pentacoordinate transition state at the phosphorous are stabilized by two protonated histidines that hydrogen bond to the attacking nucleophile and the leaving group. ${ }^{278}$ The neighboring side chain of lysine 41 adds another positive charge for electrostatic stabilization of the transition state in the active site of the ribonuclease. (b) Only the protonated N1 site of A38 is positively charged in the ultimate vicinity of the transition complex during RNA cleavage of the hairpin ribozyme. In contrast to the active site of RNAse A, in the hairpin ribozyme four additional phosphate groups within 10-13 $\AA$ of the cleavage site (G4, A5, A38, U41) destabilize the transition state by their negative charges (shown in grey). To compensate for this inherent disadvantage of ribozymes in general, at least six $\mathrm{Ca}^{2+}$ ions with a distance of 12-18 $\AA$ from the cleavage site have been identified in two crystal structures. ${ }^{202,279}$ It is interesting to note that some of these $\mathrm{Ca}^{2+}$ ions can be replaced by $\mathrm{Co}\left(\mathrm{NH}_{3}\right)_{6}{ }^{3+} \cdot{ }^{280} \mathrm{~A} 10$, which is about $9 \AA$ from the cleavable bond, has also been proposed to be protonated (not shown). ${ }^{281}$ The drawing is based on coordinates $1 \mathrm{M} 5 \mathrm{O} .{ }^{279}$

Figure 5. Catalytic centre of dialkylglycine decarboxylase. An essential $\mathrm{K}^{+}$ion is bound $11 \AA$ from the reactive aldimine nitrogen as indicated by the green dotted line. The effect of this monovalent ion is thus purely electrostatic. The $\mathrm{K}^{+}$ion is shown in magenta and bound to one water and five oxygen atoms of the protein as indicted (Leu78, Ser80, Thr303, Val305, Asp307). The substrate is shown in black. This figure has been prepared with WebLab Viewer light based on coordinates 1D7R. ${ }^{282}$ 
Figure 6. Replacement of $\mathrm{Mg}^{2+}$ with $\mathrm{K}^{+}$in the catalytic center of a group I intron. (a) $\mathrm{A} \mathrm{K}^{+}$(blue sphere) and a $\mathrm{Mg}^{2+}$ ion (magenta sphere) located in the catalytic center of a group I intron. ${ }^{90}$ Shown is the intermediate complex before exon ligation. The fully dehydrated $\mathrm{Mg}^{2+}$ ion links the 5 '-exon (dark orange) with the scissile phosphate (arrow) still linking the 3 '-exon (yellow) with the $\Omega \mathrm{dG}$ (red) of the intron (blue and green, the coloring corresponds to the one in ref. ${ }^{90}$ ). (b) The $\mathrm{K}^{+}$in (a) is now replaced with a $\mathrm{Mg}^{2+}$ (ref. ${ }^{248}$ ) underscoring the possible structural (and functional)

exchangeability of these two ions in RNAs. Note that in both structures an additional $\mathrm{Mg}^{2+}$ is located below the $\Omega$ G and only about $8.5 \AA$ away from the scissile phosphate group. By its $2+$ charge it will therefore support the reaction only electrostically. The identified coordination sphere of the metal ions in both panels is indicated by dotted lines. Both structures have been drawn with MOLMOL ${ }^{277}$ and are based on $1 \mathrm{U}^{9} \mathrm{~B}^{90}(\mathrm{a})$ and $1 \mathrm{ZZN}^{248}(\mathrm{~b})$. 


\section{Biographies}

Roland K. O. Sigel, born 1971 in Basel, Switzerland, graduated from the University of Basel with a Diploma in Chemistry in 1995. He carried out his Ph.D. thesis in the group of Professor Bernhard Lippert at the University of Dortmund, Germany, working on the effect of platinum(II) coordination on the acid-base and hydrogen-bonding properties of nucleobases and received his doctoral degree summa cum laude in 1999. From 2000-2002, he was a postdoctoral fellow at Columbia University, New York, working with Professor Anna Marie Pyle (now Yale University) on ribozymes. During the six years abroad he received several fellowships, including a European TMR Fellowship covered by the Swiss National Science Foundation and the Swiss Federal Office for Education \& Science as well as a fellowship from the Swiss Academy of Natural Sciences and the Swiss National Science Foundation. In early 2003, he returned to Switzerland and in April of this year he became an Assistant Professor of Inorganic Chemistry at the University of Zürich, endowed with a Förderungsprofessur of the Swiss National Science Foundation. His research interests are in Bioinorganic Chemistry and focus on the interrelations between metal ions and ribozymes thereby evaluating structural and catalytic impacts of metal ions by applying a broad combination of tools, including biochemical syntheses, stability-constant measurements, kinetic methods and NMR spectroscopy. Roland K. O. Sigel was a co-editor of Volumes 43 and 44 of the Metal Ions in Biological Systems series and is co-editing now the new series Metal Ions in Life Sciences (Wiley, Chichester, UK).

Anna Marie Pyle was born in 1963 and was raised in Albuquerque, New Mexico. She attended Princeton University, from which she graduated in 1985 with a B.A. in Chemistry. She carried out graduate research at Columbia University in the laboratory of Jacqueline K. Barton, where she developed phenanthrenequinone diimine complexes of transition metals and studied their interactions with DNA. After obtaining her Ph.D. in Chemistry in 1990, Dr. Pyle began postdoctoral 
February 23, 2006; Sigel \& Pyle

studies in the laboratory of Thomas R. Cech, at the University of Colorado at Boulder, where she studied molecular recognition by RNA through analysis of group I intron ribozymes. She established her own laboratory in 1992 in the Department of Biochemistry and Molecular Biophysics at Columbia University, where she began investigations on the structure and catalytic mechanisms of large group II intron ribozymes. She subsequently broadened her research program to include investigations on molecular motion by RNA helicase enzymes (a class of proteins), and to develop computational approaches for analyzing, classifying and predicting RNA tertiary structure. During her years as an assistant professor at Columbia, Dr. Pyle was a Searle Scholar, a Beckman Young Investigator, an NSF National Young Investigator and an Irma T. Hirschl scholar. In 1997, Dr. Pyle received tenure at Columbia University and was named an Assistant Investigator of the Howard Hughes Medical Institute. In 2002, Dr. Pyle transferred her laboratory to the Department of Molecular Biophysics and Biochemistry at Yale University where she is now the William Edward Gilbert Professor of Molecular Biophysics and Biochemistry and an Investigator of the Howard Hughes Medical Institute. She is a Fellow of the American Academy of Arts and Sciences and is presently the Divisional Director for Biological Sciences at Yale University. 


\section{References}

(1) Doudna, J. A.; Cech, T. R. Nature 2002, 418, 222.

(2) Lilley, D. M. J. Curr. Op. Struct. Biol. 2005, 15, 313.

(3) Fedor, M. J.; Williamson, J. R. Nature Rev. Mol. Cell Biol. 2005, 6, 399.

(4) Lehmann, K.; Schmidt, U. Critical Rev. Biochem. Mol. Biol. 2003, 38, 249.

(5) Jäschke, A.; Seelig, B. Curr. Opin. Chem. Biol. 2000, 4, 257.

(6) Jäschke, A. Curr. Opin. Struct. Biol. 2001, 11, 321.

(7) Tsukiji, S.; Ramaswamy, K.; Suga, H. Pure Appl. Chem. 2004, 76, 1525.

(8) Tsukiji, S.; Pattnaik, S. B.; Suga, H. Nature Struct. Biol. 2003, 10, 713.

(9) Lee, N.; Bessho, Y.; Weil, K.; Szostak, J. W.; Suga, H. Nat. Struct. Biol. 2000, 7, 28.

(10) Pyle, A. M. Science 1993, 261, 709.

(11) Pyle, A. M. J. Biol. Inorg. Chem. 2002, 7, 679.

(12) Narlikar, G. J.; Herschlag, D. Annu. Rev. Biochem. 1997, 66, 19.

(13) Sigel, R. K. O. Eur. J. Inorg. Chem. 2005, 12, 2281.

(14) Pyle, A. M. Met. Ions Biol. Syst. 1996, 32, 479.

(15) Nesbitt, S.; Hegg, L. A.; Fedor, M. J. Chem. Biol. 1997, 4, 619.

(16) Hampel, A.; Cowan, J. A. Chem. Biol. 1997, 4, 513.

(17) Young, K. J.; Gill, F.; Grasby, J. A. Nucleic Acids Res. 1997, 25, 3760.

(18) Murray, J. B.; Seyhan, A. A.; Walter, N. G.; Burke, J. M.; Scott, W. G. Chem. Biol. 1998, 5, 587.

(19) Earnshaw, D. J.; Gait, M. J. Nucleic Acids Res. 1998, 26, 5551.

(20) Suga, H.; Cowan, J. A.; Szostak, J. W. Biochemistry 1998, 37, 10118.

(21) Geyer, C. R.; Sen, D. Chem. Biol. 1997, 4, 579.

(22) Piccirilli, J. A.; Vyle, J. S.; Caruthers, M. H.; Cech, T. R. Nature 1993, 361, 85.

(23) Christian, E. L.; Yarus, M. Biochemistry 1993, 32, 4475. 
February 23, 2006; Sigel \& Pyle

(24) Weinstein, L. B.; Jones, B. C. N. M.; Cosstick, R.; Cech, T. R. Nature 1997, 388, 805.

(25) Basu, S.; Strobel, S. A. RNA 1999, 5, 1399.

(26) Shan, S.-O.; Yoshida, A.; Sun, S.; Piccirilli, J. A.; Herschlag, D. Proc. Natl. Acad. Sci. U. S. A. 1999, 96, 12299.

(27) Shan, S.-O.; Kravchuk, A. V.; Piccirilli, J. A.; Herschlag, D. Biochemistry 2001, 40, 5161.

(28) Yoshida, A.; Sun, S.; Piccirilli, J. A. Nat. Struct. Biol. 1999, 6, 318.

(29) Bertini, I.; Sigel, A.; Sigel, H. Handbook on Metalloproteins; Marcel Dekker Inc.: New York, 2001.

(30) Brintzinger, H. Z. Nat. Wiss. Med. Grund. 1965, 2, 188.

(31) Wolfenden, R. Accounts Chem. Res 1972, 5, 10.

(32) Prue, J. E. J. Chem. Soc. 1952, 2331.

(33) Williams, R. J. P. Endeavour 1967, 26, 104.

(34) Irving, H.; Williams, R. J. P. J. Chem. Soc. 1953, 3192.

(35) Irving, H.; Williams, R. J. P. Nature 1948, 162, 746.

(36) Tetas, M.; Lowenstein, J. M. Biochemistry 1963, 2, 350.

(37) Sigel, H. Coord. Chem. Rev. 1990, 100, 453.

(38) Erat, M. C.; Wächter, M.; Sigel, R. K. O. CHIMIA 2004, 58, 479.

(39) Kägi, J. H. R. In Metallothioneins III; Suzuki, K. T., Imura, N., Kimura, M., Eds.; Birkhäuser Verlag: Basel, 1993, 29.

(40) Sigel, H.; Song, B. Met. Ions Biol. Syst. 1996, 32, 135.

(41) Knobloch, B.; Sigel, R. K. O. results to be published

(42) Da Costa, C. P.; Sigel, H. Inorg. Chem. 2003, 42, 3475.

(43) Grosshans, C. A.; Cech, T. R. Biochemistry 1989, 28, 6888.

(44) Smith, D.; Burgin, A. B.; Haas, E. S.; Pace, N. R. J. Biol. Chem. 1992, 267, 2429.

(45) Chin, K.; Pyle, A. M. RNA 1995, 1, 391. 
February 23, 2006; Sigel \& Pyle

(46) Wrzesinski, J.; Legiewicz, M.; Smolska, B.; Ciesiolka, J. Nucleic Acids Res. 2001, 29, 4482.

(47) Erat, M. C.; Fedorova, O.; Sigel, R. K. O. manuscript to be submitted for publication

(48) Feig, A. L.; Uhlenbeck, O. C. In The RNA World; 2nd ed.; Cold Spring Harbor Laboratory Press, 1999; Vol. 37, 287.

(49) Sigel, H.; Hofstetter, F.; Martin, R. B.; Milburn, R. M.; Schellerkrattiger, V.; Scheller, K. H. J. Am. Chem. Soc. 1984, 106, 7935.

(50) Smith, C. A.; Rayment, I. Biochemistry 1996, 35, 5404.

(51) Yatsimirsky, A. K. Coord. Chem. Rev. 2005, 249, 1997.

(52) Holtz, K. M.; Stec, B.; Kantrowitz, E. R. J. Biol. Chem. 1999, 274, 8351.

(53) Sagi, I.; Hochman, Y.; Bunker, G.; Carmeli, S.; Carmeli, C. J. Synchr. Rad. 1999, 6, 409.

(54) Davies, D. R.; Hol, W. G. J. FEBS Lett. 2004, 577, 315.

(55) Sigel, H.; McCormick, D. B. Accounts Chem. Res. 1970, 3, 201.

(56) Sigel, H.; Fischer, B. E.; Prijs, B. J. Am. Chem. Soc. 1977, 99, 4489.

(57) Sigel, H. Inorg. Chem. 1980, 19, 1411.

(58) Saha, N.; Sigel, H. J. Am. Chem. Soc. 1982, 104, 4100.

(59) Sigel, H. In Coordination Chemistry - 20; Banerjea, D., Ed.; IUPAC, Pergamon Press: Oxford, 1980, 27.

(60) Sigel, H. Met. Ions Biol. Syst. 1973, 2, 63.

(61) Fischer, B. E.; Sigel, H. Inorg. Chem. 1979, 18, 425.

(62) Sigel, H.; Wyss, K.; Fischer, B. E.; Prijs, B. Inorg. Chem. 1979, 18, 1354.

(63) Einspahr, H.; Bugg, C. E. Met. Ions Biol. Syst. 1984, 17, 51.

(64) Lippert, B. Coord. Chem. Rev. 2000, 200, 487.

(65) Knobloch, B.; Suliga, D.; Okruszek, A.; Sigel, R. K. O. Chem. Eur. J. 2005, 11, 4163.

(66) Griesser, R.; Kampf, G.; Kapinos, L. E.; Komeda, S.; Lippert, B.; Reedijk, J.; Sigel, H. Inorg. Chem. 2003, 42, 32. 
February 23, 2006; Sigel \& Pyle

(67) Sigel, H. Pure Appl. Chem. 2004, 76, 1869.

(68) Knobloch, B.; Sigel, H. J. Biol. Inorg. Chem. 2004, 9, 365.

(69) Sigel, H.; Massoud, S. S.; Corfu, N. A. J. Am. Chem. Soc. 1994, 116, 2958.

(70) Knobloch, B.; Linert, W.; Sigel, H. Proc. Natl. Acad. Sci. USA 2005, 102, 7459.

(71) Kapinos, L. E.; Song, B.; Sigel, H. Chem. Eur. J. 1999, 5, 1794.

(72) Knobloch, B.; Sigel, R. K. O.; Lippert, B.; Sigel, H. Angew. Chem., Int. Ed. 2004, 43, 3793.

(73) Müller, J.; Glahé, F.; Freisinger, E.; Lippert, B. Inorg. Chem. 1999, 38, 3160.

(74) Arpalahti, J.; Klika, K. D. Eur. J. Inorg. Chem. 1999, 1199.

(75) Lippert, B. Prog. Inorg. Chem. 2005, 54, 385.

(76) Kapinos, L. E.; Holy, A.; Gunter, J.; Sigel, H. Inorg. Chem. 2001, 40, 2500.

(77) Kapinos, L. E.; Sigel, H. Inorg. Chim. Acta 2002, 337, 131.

(78) Misra, V. K.; Draper, D. E. Biopolymers 1998, 48, 113.

(79) Misra, V. K.; Draper, D. E. Proc. Natl. Acad. Sci. U. S. A. 2001, 98, 12456.

(80) Misra, V. K.; Draper, D. E. J. Mol. Biol. 1999, 294, 1135.

(81) Misra, V. K.; Draper, D. E. J. Mol. Biol. 2000, 299, 813.

(82) Misra, V. K.; Draper, D. E. J. Mol. Biol. 2002, 317, 507.

(83) Manning, G. S. Biophys. Chem. 1977, 7, 141.

(84) Manning, G. S. Quart. Rev. Biophys. 1978, 11, 179.

(85) Manning, G. S. Biopolymers 2003, 69, 137.

(86) Anderson, C. F.; Record, M. T., Jr. Biophys. Chem. 1980, 11, 353.

(87) Anderson, C. F.; Record, M. T., Jr. Annu. Rev. Phys. Chem. 1982, 33, 191.

(88) Anderson, C. F.; Record, M. T., Jr. Annu. Rev. Biophys. Biophys. Chem. 1990, 19, 423.

(89) Shkel, I. A.; Tsodikov, O. V.; Record, M. T., Jr. Proc. Natl. Acad. Sci. USA 2002, 99, 2597.

(90) Adams, P. L.; Stahley, M. R.; Kosek, A. B.; Wang, J.; Strobel, S. A. Nature 2004, 430, 45. 
February 23, 2006; Sigel \& Pyle

(91) Robinson, H.; Gao, Y. G.; Sanishvili, R.; Joachimiak, A.; Wang, A. H. J. Nucleic Acids Res. 2000, 28, 1760.

(92) Klein, D. J.; Moore, P. B.; Steitz, T. A. RNA 2004, 10, 1366.

(93) Erat, M. C.; Zerbe, O.; Fox, T.; Sigel, R. K. O. submitted for publication

(94) Sigel, R. K. O.; Sashital, D. G.; Abramovitz, D. L.; Palmer III, A. G.; Butcher, S. E.; Pyle, A. M. Nat. Struct. Mol. Biol. 2004, 11, 187.

(95) Sigel, R. K. O.; Vaidya, A.; Pyle, A. M. Nat. Struct. Biol. 2000, 7, 1111.

(96) Romer, R.; Hach, R. Eur. J. Biochem. 1975, 55, 271.

(97) Williams, R. J. P. Chem. Commun. 2003, 1109.

(98) Gray, H. B.; Malmstrom, B. G.; Williams, R. J. P. J. Biol. Inorg. Chem. 2000, 5, 551.

(99) Yamauchi, O.; Odani, A.; Masuda, H.; Sigel, H. Met. Ions Biol. Syst. 1996, 32, 207.

(100) Umezawa, Y.; Nishio, M. Nucl. Acids Res. 2002, 30, 2183.

(101) Sigel, R. K. O.; Freisinger, E.; Metzger, S.; Lippert, B. J. Am. Chem. Soc. 1998, 120, 12000.

(102) Sigel, R. K. O.; Freisinger, E.; Lippert, B. J. Biol. Inorg. Chem. 2000, 5, 287.

(103) Lüth, M. S.; Song, B.; Lippert, B.; Sigel, H. Inorg. Chem. 2000, 39, 1305.

(104) Warshel, A.; Papazyan, A. Curr. Op. Struct. Biol. 1998, 8, 211.

(105) Warshel, A. J. Biol. Chem. 1998, 273, 27035.

(106) Warshel, A. Accounts Chem. Res. 1981, 14, 284.

(107) Fersht, A. Enzyme structure and mechanism; 2nd ed.; W. H. Freeman \& Co.: New York, 1985.

(108) Tanford, C. Adv. Prot. Chem. 1962, 17, 69.

(109) Jencks, W. P. Adv. Enzymol. RAMB 1975, 43, 219.

(110) Perutz, M. F. Science 1978, 201, 1187.

(111) Warshel, A.; Levitt, M. J. Mol. Biol. 1976, 103, 227.

(112) Kokesh, F. C.; Westheimer, F. H. J. Am. Chem. Soc. 1971, 93, 7270. 
February 23, 2006; Sigel \& Pyle

(113) Highbarger, L. A.; Gerlt, J. A.; Kenyon, G. L. Biochemistry 1996, 35, 41.

(114) White, A.; Rose, D. R. Curr. Opin. Struc. Biol. 1997, 7, 645.

(115) Martin, S. F.; Hergenrother, P. J. Biochemistry 1998, 37, 5755.

(116) Inoue, M.; Yamada, H.; Yasukochi, T.; Kuroki, R.; Miki, T.; Horiuchi, T.; Imoto, T. Biochemistry 1992, 31, 5545.

(117) Bartik, K.; Redfield, C.; Dobson, C. M. Biophys. J. 1994, 66, 1180.

(118) Bevilacqua, P. C. Biochemistry 2003, 42, 2259.

(119) Martin, R. B. J. Inorg. Nucl. Chem. 1976, 38, 511.

(120) Brown, R. S.; Huguet, J.; Curtis, N. J. Met. Ions Biol. Syst. 1983, 15, 55.

(121) Milburn, R. M.; Gautam-Basak, M.; Tribolet, R.; Sigel, H. J. Am. Chem. Soc. 1985, 107, 3315.

(122) Sigel, H. Inorg. Chim. Acta 1992, 198-200, 1.

(123) Misra, V. K.; Honig, B. Proc. Natl. Acad. Sci. U. S. A. 1995, 92, 4691.

(124) Cate, J. H.; Hanna, R. L.; Doudna, J. A. Nat. Struct. Biol. 1997, 4, 553.

(125) Lewis, S. D.; Johnson, F. A.; Shafer, J. A. Biochemistry 1981, 20, 48.

(126) Storer, A. C.; Menard, R. Methods Enzymol. 1994, 244, 486.

(127) Christen, J. J.; Rytting, J. H.; Izatt, R. M. J. Chem. Soc. B 1970, 1643.

(128) Christen, J. J.; Rytting, J. H.; Izatt, R. M. Biochemistry 1970, 9, 4907.

(129) Brüning, W.; Sigel, R. K. O.; Freisinger, E.; Lippert, B. Angew. Chem., Int. Ed. 2001, 40, 3397.

(130) Sigel, R. K. O.; Thompson, S. M.; Freisinger, E.; Lippert, B. Chem. Eur. J. 2001, 7, 1968.

(131) Sigel, R. K. O.; Lippert, B. Chem. Commun. 1999, 2167.

(132) Lüth, M. S.; Willermann, M.; Lippert, B. Chem. Commun. 2001, 2058.

(133) Kesvatera, T.; Jonsson, B.; Thulin, E.; Linse, S. J. Mol. Biol. 1996, 259, 828.

(134) Kesvatera, T.; Jonsson, B.; Thulin, E.; Linse, S. Proteins 2001, 45, 129. 
February 23, 2006; Sigel \& Pyle

(135) Harris, T. K.; Turner, G. J. IUBMB Life 2002, 53, 85.

(136) Schweins, T.; Scheffzek, K.; Assheuer, R.; Wittinghofer, A. J. Mol. Biol. 1997, 266, 847.

(137) Matte, A.; Delbaere, L. T. J. In Handbook on Metalloproteins; Bertini, I., Sigel, A., Sigel, H., Eds.; Marcel Dekker Inc.: New York, Basel, 2001, 59.

(138) Oda, Y.; Yamazaki, T.; Nagayama, K.; Kanaya, S.; Kuroda, Y.; Nakamura, H. Biochemistry 1994, 33, 5275 .

(139) Jou, R. W.; Cowan, J. A. J. Am. Chem. Soc. 1991, 113, 6685.

(140) Auld, D. S. In Handbook on Metalloproteins; Bertini, I., Sigel, A., Sigel, H., Eds.; Marcel Dekker Inc.: New York, Basel, 2001, 881.

(141) Hightower, K. E.; Huang, C. C.; Casey, P. J.; Fierke, C. A. Biochemistry 1998, 37, 15555.

(142) Ploegman, J. H.; Drent, G.; Kalk, K. H.; Hol, W. G. J. J. Mol. Biol. 1979, 127, 149.

(143) Baldwin, G. S.; Gormley, N. A.; Halford, S. E. Met. Ions Biol. Syst. 2000, 37, 345.

(144) Selent, U.; Ruter, T.; Kohler, E.; Liedtke, M.; Thielking, V.; Alves, J.; Oelgeschlager, T.; Wolfes, H.; Peters, F.; Pingoud, A. Biochemistry 1992, 31, 4808.

(145) Viadiu, H.; Aggarwal, A. K. Nat. Struct. Biol. 1998, 5, 910.

(146) Xu, S. Y.; Schildkraut, I. J. Biol. Chem. 1991, 266, 4425.

(147) Xu, S. Y.; Schildkraut, I. J. Bacteriol. 1991, 173, 5030.

(148) Casareno, R. L. B.; Li, D. W.; Cowan, J. A. J. Am. Chem. Soc. 1995, 117, 11011.

(149) Chowrira, B. M.; Berzal-Herranz, A.; Burke, J. M. Biochemistry 1993, 32, 1088.

(150) Sigel, H.; Tribolet, R. J. Inorg. Biochem. 1990, 40, 163.

(151) Lu, Q.; Martell, A. E.; Motekaitis, R. J. Inorg. Chim. Acta 1996, 251, 365.

(152) Lu, Q.; Carroll, R. I.; Reibenspies, J. H.; Martell, A. E.; Clearfield, A. J. Mol. Struct. 1998, $470,121$.

(153) Sigel, H.; Griesser, R. Chem. Soc. Rev. 2005, 34, 875.

(154) Legault, P.; Pardi, A. J. Am. Chem. Soc. 1997, 119, 6621. 
February 23, 2006; Sigel \& Pyle

(155) Blanchard, S. C.; Puglisi, J. D. Proc. Natl. Acad. Sci. USA 2001, 98, 3720.

(156) Huppler, A.; Nikstad, L. J.; Allmann, A. M.; Brow, D. A.; Butcher, S. E. Nat. Struct. Biol. 2002, 9,431 .

(157) Jang, S. B.; Hung, L. W.; Chi, Y. I.; Holbrook, E. L.; Carter, R. J.; Holbrook, S. R. Biochemistry 1998, 37, 11726.

(158) Sashital, D. G.; Cornilescu, G.; Butcher, S. E. Nature Struct. Mol. Biol. 2004, 11, 1237.

(159) Reiter, N. J.; Blad, H.; Abildgaard, F.; Butcher, S. E. Biochemistry 2004, 43, 13739.

(160) Flinders, J.; Dieckmann, T. J. Mol. Biol 2001, 308, 665.

(161) Flinders, J.; Dieckmann, T. J. Mol. Biol. 2004, 341, 935.

(162) Leontis, N. B.; Westhof, E. Quart. Rev. Biophys. 1998, 31, 399.

(163) Moody, E. M.; Lecomte, J. T. J.; Bevilacqua, P. C. RNA 2005, 11, 157.

(164) Bevilacqua, P. C.; Brown, T. S.; Nakano, S.-i.; Yajima, R. Biopolymers 2004, 73, 90.

(165) Takagi, Y.; Ikeda, Y.; Taira, K. Top. Curr. Chem. 2004, 232, 213.

(166) Sigel, R. K. O. Effect of platinum(II) coordination on the acid-base and hydrogen-bonding properties of nucleobases: Association patterns in solution and the solid state; Logos Verlag: Berlin, 1999.

(167) Garijo Anorbe, M.; Luth, M. S.; Roitzch, M.; Cerda, M. M.; Lax, P.; Kampf, G.; Sigel, H.; Lippert, B. Chem. Eur. J. 2004, 10, 1046.

(168) Petrov, A. S.; Lamm, G.; Pack, G. R. J. Phys. Chem. B 2002, 106, 3294.

(169) Shui, X. Q.; McFail-Isom, L.; Hu, G. G.; Williams, L. D. Biochemistry 1998, 37, 8341.

(170) Cate, J. H.; Doudna, J. A. Structure 1996, 4, 1221.

(171) Munoz, J.; Gelpi, J. L.; Soler-Lopez, M.; Subirana, J. A.; Orozco, M.; Luque, F. J. J. Phys. Chem. B 2002, 106, 8849 .

(172) Soler-Lopez, M.; Malinina, L.; Liu, J.; Huynh-Dinh, T.; Subirana, J. A. J. Biol. Chem. 1999, 274, 23683. 
February 23, 2006; Sigel \& Pyle

(173) Soler-Lopez, M.; Malinina, L.; Subirana, J. A. J. Biol. Chem. 2000, 275, 23034.

(174) Borda, E. J.; Markley, J. C.; Sigurdsson, S. T. Nucl. Acid. Res. 2003, 31, 2595.

(175) Murray, J. B.; Dunham, C. M.; Scott, W. G. J. Mol. Biol. 2002, 315, 121.

(176) Sigel, H. Chem. Soc. Rev. 1993, 22, 255.

(177) Sigel, H.; Martin, R. B. Chem. Soc. Rev. 1994, 23, 83.

(178) Reinert, H.; Weiss, R. H.-S. Z. Physiol. Chem. 1969, 350, 1321.

(179) Yano, S.; Otsuka, M. Met. Ions Biol. Syst. 1996, 32, 27.

(180) Poonia, N. S.; Bajaj, A. V. Chem. Rev. 1979, 79, 389.

(181) Dheu-Andries, M. L.; Perez, S. Carbohyd. Res. 1983, 124, 324.

(182) Brown, E. A.; Bugg, C. E. Acta Crystallogr. B 1980, 36, 2597.

(183) Sigel, H.; Lippert, B. Pure Appl. Chem. 1998, 70, 845.

(184) Knobloch, B.; Sigel, H.; Okruszek, A.; Sigel, R. K. O. Org. Biomol. Chem. 2006, 4, DOI: 10.1039/b517904a.

(185) Sigel, R. K. O.; Song, B.; Sigel, H. J. Am. Chem. Soc. 1997, 119, 744.

(186) Da Costa, C. P.; Okruszek, A.; Sigel, H. ChemBioChem 2003, 4, 593.

(187) Mareque-Rivas, J. C.; Prabaharan, R.; de Rosales, R. T. Chem. Commun. 2004, 76.

(188) Kluge, S.; Weston, J. Biochemistry 2005, 44, 4877.

(189) Lindqvist, M.; Sandström, K.; Liepins, V.; Strömberg, R.; Gräslund, A. RNA 2001, 7, 1115.

(190) Sharp, K. A.; Honig, B. Annu. Rev. Biophys. Bio. 1990, 19, 301.

(191) Soman, K.; Yang, A. S.; Honig, B.; Fletterick, R. Biochemistry 1989, 28, 9918.

(192) Russell, A. J.; Fersht, A. R. Nature 1987, 328, 496.

(193) Tweedy, N. B.; Hurle, M. R.; Chrunyk, B. A.; Matthews, C. R. Biochemistry 1990, $29,1539$.

(194) Rogers, N. K.; Moore, G. R.; Sternberg, M. J. E. J. Mol. Biol. 1985, 182, 613.

(195) Linse, S.; Brodin, P.; Johansson, C.; Thulin, E.; Grundstrom, T.; Forsen, S. Nature 1988, 335, 651. 
February 23, 2006; Sigel \& Pyle

(196) Russell, A. J.; Thomas, P. G.; Fersht, A. R. J. Mol. Biol. 1987, 193, 803.

(197) Jackson, S. E.; Fersht, A. R. Biochemistry 1993, 32, 13909.

(198) Fersht, A. R.; Sternberg, M. J. E. Protein Eng. 1989, 2, 527.

(199) Gilson, M. K.; Honig, B. H. Nature 1987, 330, 84.

(200) Sternberg, M. J. E.; Hayes, F. R. F.; Russell, A. J.; Thomas, P. G.; Fersht, A. R. Nature 1987, 330,86 .

(201) Sun, D. P.; Liao, D. I.; Remington, S. J. Proc. Natl. Acad. Sci. U. S. A. 1989, 86, 5361.

(202) Rupert, P. B.; Ferre-D'Amare, A. R. Nature 2001, 410, 780.

(203) Feig, A. L.; Scott, W. G.; Uhlenbeck, O. C. Science 1998, 279, 81.

(204) Scott, W. G. Methods 2002, 28, 302.

(205) Murray, J. B.; Terwey, D. P.; Maloney, L.; Karpeisky, A.; Usman, N.; Beigelman, L.; Scott, W. G. Cell 1998, 92, 665.

(206) Black, C. B.; Cowan, J. A. Eur. J. Biochem. 1997, 243, 684.

(207) Lau, M. W. L.; Cadieux, K. E. C.; Unrau, P. J. J. Am. Chem. Soc. 2004, 126, 15686.

(208) Eisenfuhr, A.; Arora, P. S.; Sengle, G.; Takaoka, L. R.; Nowick, J. S.; Famulok, M. Bioorg. Med. Chem. 2003, 11, 235.

(209) Baskerville, S.; Bartel, D. P. Proc. Nat. Acad. Sci. U. S. 2002, 99, 9154.

(210) Sun, L.; Cui, Z.; Gottlieb, R. L.; Zhang, B. Chem. \& Biol. 2002, 9, 619.

(211) Jaschke, A. Biol. Chem. 2001, 382, 1321.

(212) Lohse, P. A.; Szostak, J. W. Nature 1996, 381, 442.

(213) Kieft, J. S.; Tinoco, I., Jr. Structure 1997, 5, 713.

(214) Draper, D. E.; Grilley, D.; Soto, A. M. Annu. Rev. Biophys. Biomol. Struct. 2005, 34, 221.

(215) Flynn-Charlebois, A.; Lee, N.; Suga, H. Biochemistry 2001, 40, 13623.

(216) Colmenarejo, G.; Tinoco Jr., I. J. Mol. Biol. 1999, 290, 119.

(217) Hermann, T.; Westhof, E. Struct. Fold. Des. 1998, 6, 1303. 
February 23, 2006; Sigel \& Pyle

(218) Chin, K.; Sharp, K. A.; Honig, B.; Pyle, A. M. Nat. Struct. Biol. 1999, 6, 1055.

(219) Chiu, T. K.; Dickerson, R. E. J. Mol. Biol. 2000, 301, 915.

(220) Baeyens, K. J.; DeBondt, H. L.; Pardi, A.; Holbrook, S. R. Proc. Natl. Acad. Sci. USA 1996, $93,12851$.

(221) Valls, N.; Wright, G.; Steiner, R. A.; Murshudov, G. N.; Subirana, J. A. Acta Crystallogr. D 2004, 60, 680 .

(222) Abrescia, N. G. A.; Huynh-Dinh, T.; Subirana, J. A. J. Biol. Inorg. Chem. 2002, 7, 195.

(223) Sigel, H. Eur. J. Biochem. 1987, 165, 65.

(224) Kiriukhin, M. Y.; Collins, K. D. Biophys. Chem. 2002, 99, 155.

(225) Lincoln, S. F. Helv. Chim. Acta 2005, 88, 523.

(226) Boyer, P. D.; Lardy, H. A.; Phillips, P. H. J. Biol. Chem. 1942, 146, 673.

(227) Kachmar, J. F.; Boyer, P. D. J. Biol. Chem. 1953, 200, 669.

(228) Evans, H. J.; Sorger, G. J. Ann. Rev. Plant. Physio. 1966, 17, 47.

(229) Suelter, C. H. Science 1970, 168, 789.

(230) Suelter, C. H. Met. Ions Biol. Syst. 1974, 3, 201.

(231) Larsen, T. M.; Reed, G. H. In Handbook on Metalloproteins; Bertini, I., Sigel, A., Sigel, H., Eds.; Marcel Dekker Inc.: New York, Basel, 2001, 9.

(232) Toney, M. D.; Hohenester, E.; Cowan, S. W.; Jansonius, J. N. Science 1993, 261, 756.

(233) Wong, A.; Wu, G. J. Am. Chem. Soc. 2003, 125, 13895.

(234) Freisinger, E.; Schimanski, A.; Lippert, B. J. Biol. Inorg. Chem. 2001, 6, 378.

(235) Fischer, B.; Preut, H.; Lippert, B.; Schollhorn, H.; Thewalt, U. Polyhedron 1990, 9, 2199.

(236) Cheong, C. J.; Moore, P. B. Biochemistry 1992, 31, 8406.

(237) Urbanke, C.; Romer, R.; Maass, G. Eur. J. Biochem. 1975, 55, 439.

(238) Cole, P. E.; Crothers, D. M. Biochemistry 1972, 11, 4368. 
February 23, 2006; Sigel \& Pyle

(239) Phillips, K.; Dauter, Z.; Murchie, A. I. H.; Lilley, D. M. J.; Luisi, B. J. Mol. Biol. 1997, 273, 171.

(240) Basu, S.; Rambo, R. P.; Strauss-Soukup, J.; Cate, J. H.; Ferre-D'Amare, A. R.; Strobel, S. A.; Doudna, J. A. Nat. Struct. Biol. 1998, 5, 986.

(241) Curtis, E. A.; Bartel, D. P. RNA 2001, 7, 546.

(242) O'Rear, J. L.; Wang, S.; Feig, A. L.; Beigelman, L.; Uhlenbeck, O. C.; Herschlag, D. RNA 2001, 7, 537.

(243) Conn, G. L.; Gittis, A. G.; Lattman, E. E.; Misra, V. K.; Draper, D. E. J. Mol. Biol. 2002, 318, 963.

(244) Draper, D. E. RNA 2004, 10, 335.

(245) Shiman, R.; Draper, D. E. J. Mol. Biol. 2000, 302, 79.

(246) Tereshko, V.; Wilds, C. J.; Minasov, G.; Prakash, T. P.; Maier, M. A.; Howard, A.; Wawrzak, Z.; Manoharan, M.; Egli, M. Nucl. Acids Res. 2001, 29, 1208.

(247) Basu, S.; Strobel, S. A. Methods 2001, 23, 264.

(248) Stahley, M. R.; Strobel, S. A. Science 2005, 309, 1587.

(249) Thorpe, J. H.; Gale, B. C.; Teixeira, S. C. M.; Cardin, C. J. J. Mol. Biol. 2003, 327, 97.

(250) Williamson, J. R.; Raghuraman, M. K.; Cech, T. R. Cell 1989, 59, 871.

(251) Parkinson, G. N.; Lee, M. P. H.; Neidle, S. Nature 2002, 417, 876.

(252) Pan, B.; Xiong, Y.; Shi, K.; Sundaralingam, M. Structure 2003, 11, 825.

(253) Gluick, T. C.; Gerstner, R. B.; Draper, D. E. J. Mol. Biol. 1997, 270, 451.

(254) Jaeger, J. A.; Zuker, M.; Turner, D. H. Biochemistry 1990, 29, 10147.

(255) Smith, R. M.; Martell, A. E.; Chen, Y. Pure Appl. Chem. 1991, 63, 1015.

(256) Iversen, G.; Kharkats, Y. I.; Ulstrup, J. Mol. Phys. 1998, 94, 297.

(257) Sigel, H.; Martin, R. B.; Tribolet, R.; Haring, U. K.; Malinibalakrishnan, R. Eur. J. Biochem. 1985, $152,187$. 
February 23, 2006; Sigel \& Pyle

(258) Bastian, M.; Sigel, H. Inorg. Chim. Acta 1990, 178, 249; see footnote on page 258.

(259) Rees, D. C. J. Mol. Biol. 1980, 141, 323.

(260) Teeter, M. M. Annu. Rev. Biophys. Biophys. Chem. 1991, 20, 577.

(261) De Meis, L. Biochim. Biophys. Acta 1989, 973, 333.

(262) Sigel, H. Pure and Applied Chemistry 1989, 61, 923.

(263) Williamson, M. P.; Williams, D. H. Eur. J. Biochem. 1984, 138, 345.

(264) Head-Gordon, T. Proc. Natl. Acad. Sci. USA 1995, 92, 8308.

(265) Kankia, B. I.; Marky, L. A. J. Phys. Chem. B 1999, 103, 8759.

(266) Chiu, T. K.; Kaczor-Grzeskowiak, M.; Dickerson, R. E. J. Mol. Biol. 1999, 292, 589.

(267) Freisinger, E.; Fernandes, A.; Grollman, A. P.; Kisker, C. J. Mol. Biol. 2003, 329, 685.

(268) Israelachvili, J.; Wennerstrom, H. Nature 1996, 379, 219.

(269) Dudev, T.; Lim, C. J. Phys. Chem. B 2000, 104, 3692.

(270) Liang, G. G.; Corfu, N. A.; Sigel, H. Z. Naturforsch. B 1989, 44, 538.

(271) Bianchi, E. M.; Griesser, R.; Sigel, H. Helv. Chim. Acta 2005, 88, 406.

(272) Liang, G.; Chen, D.; Bastian, M.; Sigel, H. J. Am. Chem. Soc. 1992, 114, 7780.

(273) Sigel, H.; Da Costa, C. P.; Song, B.; Carloni, P.; Gregan, F. J. Am. Chem. Soc. 1999, 121, 6248.

(274) Bott, R.; Ultsch, M.; Kossiakoff, A.; Graycar, T.; Katz, B.; Power, S. J. Biol. Chem. 1988, 263,7895 .

(275) Kuzmin, Y. I.; Da Costa, C. P.; Fedor, M. J. J. Mol. Biol. 2004, 340, 233.

(276) Ferre-D'Amare, A. R. Biopolymers 2004, 73, 71.

(277) Koradi, R.; Billeter, M.; Wüthrich, K. J. Mol. Graphics 1996, 14, 29.

(278) Raines, R. T. Chem. Rev. 1998, 98, 1045.

(279) Rupert, P. B.; Massey, A. P.; Sigurdsson, S. T.; Ferre-D'Amare, A. R. Science 2002, 298, 1421. 
February 23, 2006; Sigel \& Pyle

(280) Alam, S.; Grum-Tokars, V.; Krucinska, J.; Kundracik, M. L.; Wedekind, J. E. Biochemistry 2005, 44, 14396.

(281) Ryder, S. P.; Oyelere, A. K.; Padilla, J. L.; Klostermeier, D.; Millar, D. P.; Strobel, S. A. RNA 2001, 7, 1454.

(282) Malashkevich, V. N.; Strop, P.; Keller, J. W.; Jansonius, J. N.; Toney, M. D. J. Mol. Biol. 1999, 294, 193. 